九州大学学術情報リポジトリ

Kyushu University Institutional Repository

\title{
Sandstones of the Cretaceous Mifuné Group, Kyushu, Japan
}

Okada, Hakuyu

Faculty of Sciences, Kyushu University

https://doi.org/10.5109/1526103

出版情報：九州大學理學部紀要：Series D, Geology. 10 (1)，pp.1-40，1960-12-20. Faculty of Science, Kyushu University バージョン :

権利関係 : 
Mem. Fac. Sci., Kyushu Univ., Ser. D, Geology, Vol. X, No. 1, pp. 1-40, text-figs. 1-16, pls. 1-5, December 20, 1960

\title{
Sandstones of the Cretaceous Mifuné Group, Kyushu, Japan
}

\author{
By
}

\section{Hakuyu OKADA}

\begin{abstract}
The sandstones of the Mifuné group, which constitutes a central part of the Cretaceous basins characterized by red beds in Middle Kyushu, are assigned to the graywacke suite. They are studied petrologically with reference to their mineral composition and texture. Comments are given on the significance of the results. In addition, notes on tuffaceous rocks and red beds are also presented.

The graywacke-type sandstones of the Mifuné group are rather rich in matrix. The feldspar content is very low. They are characterized by a predominant heavy mineral of epidote which is an index mineral of the Mifuné. The tuffaceous rocks are characterized by apatite.

The detritus is primarily of crystalline metamorphic, acid igneous, and sedimentary origins. Problems of the source rocks are in detail commented.

Relations between tectonics and sedimentation are discussed, and the red coloration of the sediments is also referred to.

The Cretaceous red beds of Mifuné are compared to the Triassic Newark series of Connecticut in some respects.
\end{abstract}

\section{Introduction}

\section{Purpose of study}

The Cretaceous Mifuné group constitutes one of the characteristic basins in Middle Kyushu, containing reddish sediments, together with the contemporaneous Goshonoura group on the western side and Onogawa group on the eastern side.

Matsumoтo (1936, 1938, 1939a) clarified their stratigraphic sequences, facies, gelogical ages, and structures. Their geological significance has been discussed by Matsumoto $(1936,1938,1939 \mathrm{a}, 1939 \mathrm{~b}, 1954)$ and others (Kobayashi et al., 1936; Kobayashi, 1941, 1954 ; OKada, 1958).

Professor Tatsuro Matsumoto suggested me to scrutinize more profoundly the Mifune group on the basis of these previous investigations. The emphasis has been focussed on the petrological study of the sandstones of the Mifuné group, primarily because sandstones reflect the provenance and tectonic condition very intensely.

The purpose of this study is a better appraisal of source areas, of the physical factors that influenced sedimentation at the site of deposition, and of the rock patterns, all of which will lead to a better understanding of a relation between tectonics and sedimentation in this period. 
In this paper I give at length the descriptions of the petrographic facts, that were observed and measured as quantitatively as possible, and then attempt to discuss petrologically these problems.

\section{Notes on stratigraphy}

The Cretaceous deposits of the Mifuné group overlie with a remarkable unconformity a group of green schists with accompanied serpentinite on the northern side and the Upper Permian Mizukoshi formation (Matsumoto et al., 1939; YanaGida, 1958) on the southern side, forming a synclinorium.

An excellent background of stratigraphic information is contained in the two

$\mathbf{N}$

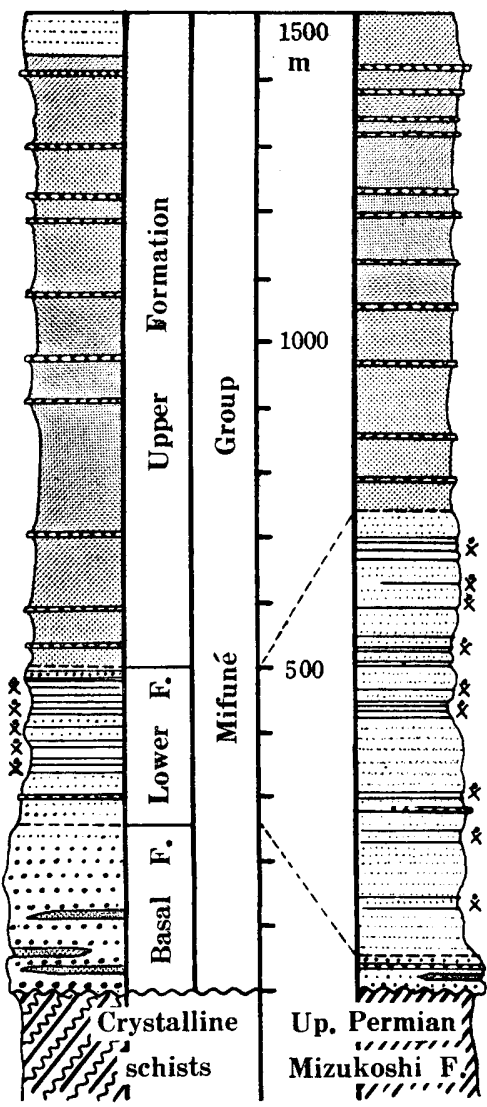

Fig. 2. Stratigraphical section of the Mifuné group (adapted from Matsumoto, 1939a).

Explanation:

$\mathrm{N}$ : Northern wing of the Mifuné group

S: Southern wing of the ditto. Darkened parts stand for prevailing red sediments papers by Matsumoto (1939a, 1954).

Text-fig. 1 is the geologic map of the Mifuné area investigated, which is adapted from MATsuмото (1939a). The general stratigraphy is illustrated in Text-fig. 2.

The Mifuné group, with a total thickness of 1,500 meters, represents a cycle of sedimentation. It is divided into the three formations, which are called, as originally defined, Basal, Lower, and Upper formations.

As Matsumoto (1954, p. 198, Fig. 43) pointed out, the coarse clastic ratio is lower in this entire basin than in the other contemporaneous basins of the Onogawa group as well as the Goshonoura group in Middle Kyushu.

(1) Basal formation.-In the Basal formation coarse clastics of conglomerate and conglomeratic very coarse-grained sandstone are major constituents, while mudstone or shale of reddish color is concomitantly intercalated at a few horizons. The clasic-shale ratio, however, decreases in values from the northern wing of the syncline to the southern wing across the basin, as does the thickness of the formation from 250 meters on the northern wing to only 50 meters on the southern wing.

On the northern wing are predominant boulder-bearing cobble- to pebble-conglomerates with reddish matrix, which are rather fanglomeratic in aspect (Pl. 1, Fig. 1). On the contrary, 


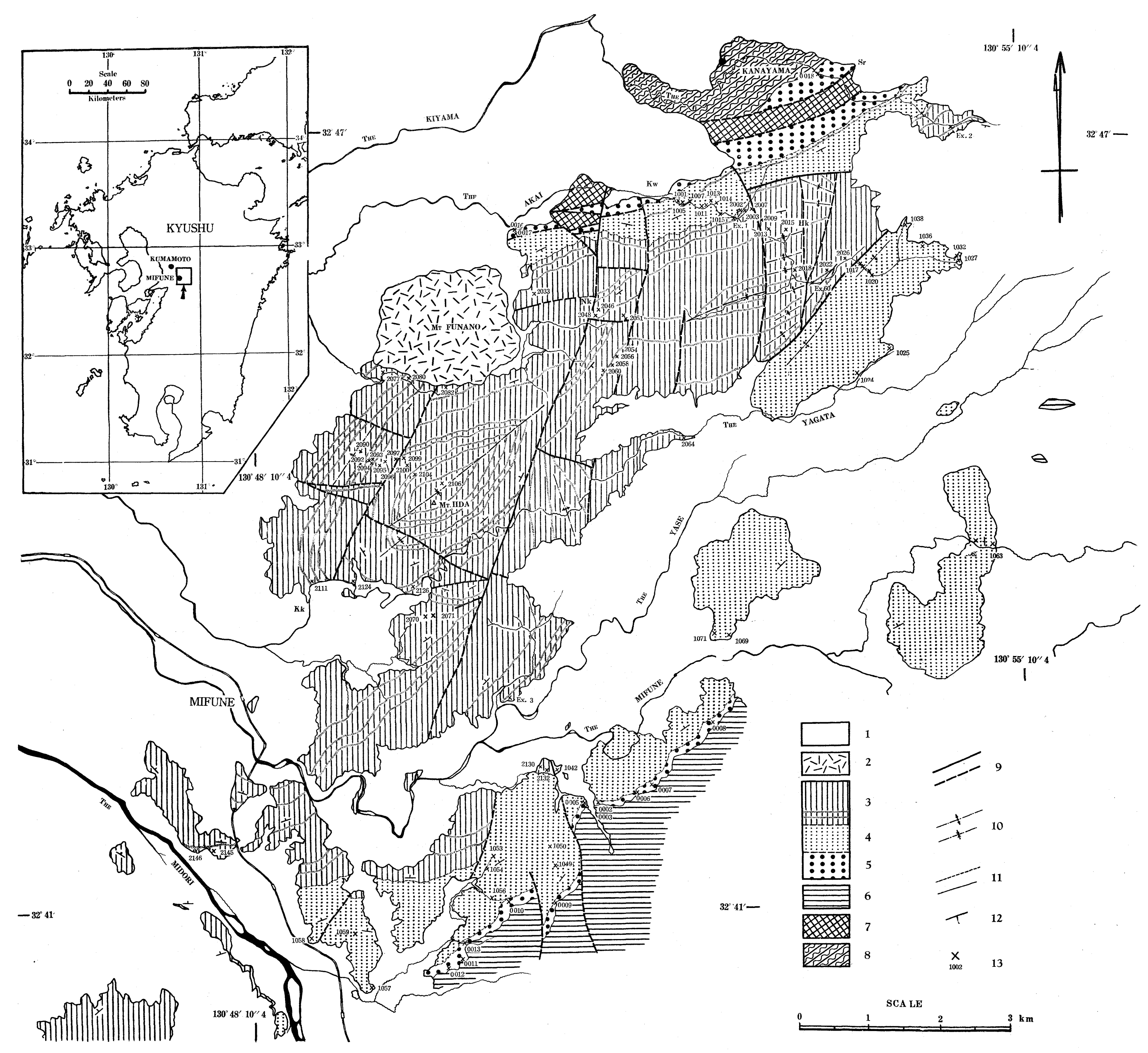

Fig. 1. Geological map of the Mifuné area (adapted from MATsumoro, 1939a) and location of petrographical samples. Explanation :

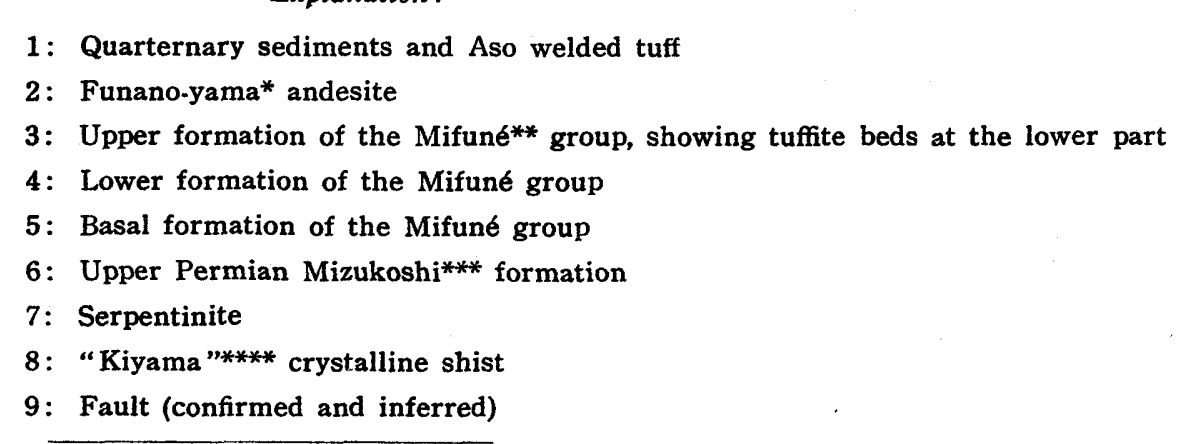

10: axes of anticline and syncline

11: Bounday of the formations (conformable and unconformable)

12: Strike and dip

13: Location of rock samples

Sr: Sarugayeri*****

KW : Kawachida******

Hk: Hakamano*******

Fk: Nakano********

Kk: Kitakinokura********

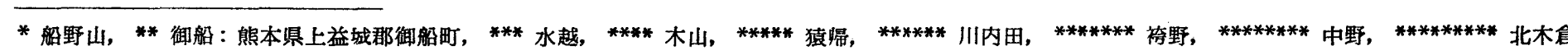


on the southern wing the basal conglomerate gets trivial, and, in turn, sandstone and shale come out predominant. This formation is easily traceable for a long distance with a characteristic reddish appearance, but no fossil remains have been found as yet in this formation.

Conglomerate comprises pebbles of porphyries, dasites, crystalline schists, phyllite, chert, slate, and serpentinite on the northern wing, whereas on the southern wing are contained pebbles of sandstone and/or shale from the underlying Mizukoshi formation in addition to the above.

(2) Lower formation.-This consists mainly of sandstones and shales in almost equal proportions, with minor amount of other rocks.

On the northern wing, its basal part is conglomeratic or coarse-grained sandstones, showing cross-lamination (P1. 1, Fig. 2). In the main part of the formation the sandstone is alternated with shale, being more frequently so in the upper part than in the lower. Sandstones are in general greenish grey and, when weathered, pale brownish orange in color. Shale is deeply gray or blackish. Marine molluscs of pelecypod and gastropod* are quite abundant, which indicate the brackish environment. There is a dark-colored argillaceous limestone, probably in a lenticular form, in the uppermost part of the formation immediately below the Upper formation. Shales adjacent to the limestone are also more or less calcareous.

On the southern wing, the Lower formation is different in lithologic features as well as in thickness from that on the northern wing; the formation on the former, 250 meters thick, is three times as great as that on the latter, 750 meters thick. Sandstones are rather predominant at the lower horizons, being more or less massive in occurrence. Molluscan fossils of the open sea environment are contained.

(3) Upper formation.-The Upper formation is characterized by the red sediments, which account for 40 percent of the whole deposits on the northern wing and about 35 percent on the southern wing (MAтsumoto [Editor], 1954, p. 198, Fig. 43). These predominant red and variegated sediments are composed mainly of shales and siltstones, being subordinately accompanied by the greenish beds mainly composed of sandstones (P1. 1, Figs. 3-6), A small quantity of sandstones has a red tint. Therefore sandstone-shale ratio is smallest of the three formations of the Mifuné group, but sandstones increase towards the uppermost part.

As to the sedimentary structure, cross-bedding is not uncommon, and ripple marks are occasionally found. Other minor sedimentary structures such as sand pipes and calcareous concretions are sometimes found in shales and siltstones.

Regarding fossils, only latifoliate remains of Platanus sp., etc., were found from a limited part.

\footnotetext{
* For an account of the fossils of the Mifuné group, the reader is referred to the papers of Matsumoto (1939a), Matsumoto [Editor] (1954), and Okada (1958).
} 
From the fossil evidence, the main part of the Mifune group is correlated to the Gyliakian, the approximate equivalent of the European Cenomanian to Turonian, and its lower part to the upper stage of the Miyakoan, the approximate equivalent of the European Albian (Matsumoto, 1939a; Matsumoto [Editor], 1954).

\section{Acknowledgements}

I wish to express my most sincere thanks to Professor Tatsuro Matsumoto who suggested this study and who has been a supervisor with a constant encouragement, providing me not only with various facilities for study but also with helpful suggestions and criticisms for its improvement. My special thanks are due to Professor Tōru Tomita of the Kyushu University for his helpful suggestions and critical discussions. I am also indebted to Professor Ryuzo TorIYAma of the Kyushu University who gave me many facilities for this study. In particular, to Mr. Koji FuJII of the Onoda Cement Co., Ltd., I am much indebted for his continued encouragement to my efforts, for his valuable advices concerning the experimental design, and for his helpful discussions. Others who helped my study in various ways were; Assistant Professors Kametoshi Kanmera, Haruo Shirozu, and Tsugio Shuto, Messrs. Yoshifumi Karakida, Yukio Matsumoto, Jyōnosuke Ohara, Yoshiro Ueda, Mayumi Yoshinaga, and Juichi Yanagida, Mrs. Yeiko Yoshinaga of the Kyushu University, Dr. Kunihiko Muta of the Sumitomo Metal Mining Co., Ltd., Late Dr. Yohachiro OKamoto, and Takeshi AKatsu of the Yahata Chemical Industry Co., Ltd., and Assistant Professors Kazuo YAMAOKA of the Tohoku University (formerly of the Kumamoto University) and Hisashi Kusumi of the Hiroshima University. Further, I wish to acknowledge my indebtedness to the friends who kindly gave me many facilities for my field work. Miss Chizuko OKamura assisted in typewriting the manuscript.

This study was financially brought to completion through Professor Tatsuro Matsumoto by the Grant in Aid for Scientific Researches from the Ministry of Education, Japan.

\section{Petrographic Descriptions}

\section{Procedure}

The samples were collected according to a predetermined design to ensure adequate geographic and stratigraphic coverage as effectively as possible throughout the areas where the Mifuné group crops out (Text-fig. 1).

Standard methods of petrographic study were applied for all the sandstone samples. From thin sections were determined and measured the textural elements of the rocks as well as relative abundance of the major constituents.

Evaluation of grain-size distribution was microscopically made from thin sections. KRUMBEIN's method (1935) of size distribution analysis of coagulated sandstones was 
adopted: the maximum diameters of more than 200 quartz grains per slide were measured, and median diameter together with standard deviation was evaluated after his formula. For graphic representation of the results measured was used his $p h i$-scale (Krumbein, 1936). No attempt was made to measure grains smaller than $6.0 \phi(0.002 \mathrm{~mm})$. The reason why the measurement was restricted to quartz grains is that quartz is most stable and is left unaltered so that its definite boundaries enable us to do rapid measurements.

As to the roundness of the grains, which was also evaluated mainly on the quartz grains, the visual chart prepared by KRUMBeIN (1941) was used. It goes without saying that the estimation of roundness was confined to the grains coarser than the medium-sand.

Regarding the relative abundance of the major constituents of the rocks were measured quartz, chert, feldspar, calcite, rock fragments, and matrix from thin sections by means of the micro-integrator.

Heavy mineral analysis was made of almost all of the sandstone samples on which textural and other analyses were in parallel carried out as stated above. Method of separating heavy minerals is almost similar to IIJIMA (1959b), although the coarser fractions of crushed sandstone were removed by sieving through the S.S. 80 mesh sieve, the finer ones having been removed in water, and a common glass funnel of an obtuse angle was used for heavy mineral separation. Heavy liquid used is Thoulet's solution (S.G. $=2.9$ ). On analysing heavy minerals separated, 200 to 250 grains were counted to estimate heavy mineral composition.

On some particular samples the X-ray analysis, D.T.A., and chemical analysis were attempted to obtain supplementary and more reliable data, in the cases of which the FrANTZ Isodynamic Separator was used to select samples as purely as possible.

\section{Error}

In thin-section analysis, a micro-integrator was used to evaluate mineral composition in that operational variation is not significant at the utmost at the 4 percent or even at the 1 or less percent level, as is tabulated in Table 1.

Concerning heavy mineral analysis, errors in counting mineral grains have already been theoretically and experimentally examined by many authors (e.g. Dryden, 1935 ; IIJIMA, 1959b; etc.), so no additional attempt was done.

\section{Textures}

(1) Grain size distribution.-By measuring a long dimension of 200 and more grains, large enough to measure individuals, the median diameter and the standard deviation were calculated. Since the results thus obtained do not indicate genuine 
Table 1. Operational variation in estimating major constituents of a sandstone sample $\nmid$

\begin{tabular}{c|cccccc}
\hline Timestt & Quartz & Chert & Feldspar & Matrix & Rock fragments & Micas \\
\hline 1 & 21 & $\operatorname{tr}$ & 35 & 40 & 3 & $\mathrm{tr}$ \\
2 & 21 & 1 & 35 & 40 & 3 & $\mathrm{tr}$ \\
3 & 20 & 1 & 36 & 41 & 2 & $\mathrm{tr}$ \\
4 & 18 & $\operatorname{tr}$ & 36 & 43 & 3 & $\mathrm{tr}$ \\
5 & 19 & $\operatorname{tr}$ & 34 & 43 & 3 & $\mathrm{tr}$ \\
6 & 19 & $\operatorname{tr}$ & 36 & 42 & 3 & $\mathrm{tr}$ \\
7 & 19 & $\operatorname{tr}$ & 34 & 43 & 3 & $\mathrm{tr}$ \\
8 & 17 & $\operatorname{tr}$ & 37 & 43 & 3 & $\mathrm{tr}$ \\
9 & 19 & $\operatorname{tr}$ & 35 & 43 & 2 & $\mathrm{tr}$ \\
10 & 21 & $\operatorname{tr}$ & 33 & 43 & 3 & $\mathrm{tr}$ \\
\hline
\end{tabular}

$\dagger$ Sp. No. MF. 2041; from the Upper formation.

H Each estimation was inconsecutively made on the different day.

grain sizes, the availability of the data is primarily comparative. Table 2 contains the results measured and calculated.

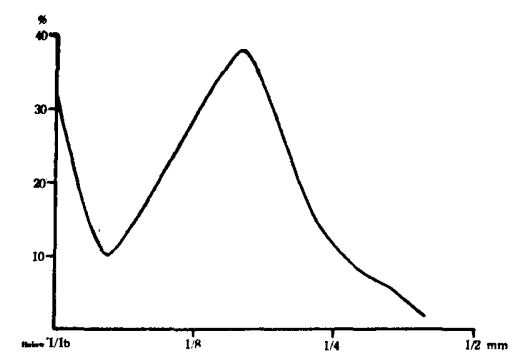

Fig. 3. Size distribution curve of quartz grains : A type. Sp. No. MF. 1027

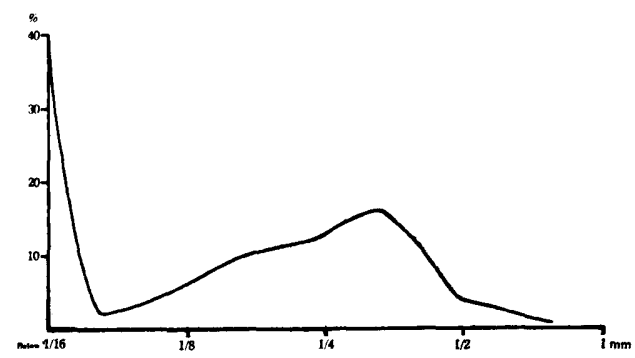

Fig. 4. Size distribution curve of quartz grains: B type.

Sp. No. MF. 1030

The clay matrix must be taken into consideration, because it is a primary detrital constituents. This procedure puts it into one class. The size distribution curve obtained in such a way is typically bimodal (Text-figs. 3, 4). FUJI (1954) studied the sandstones of the Mesozoic formations in the Yatsushiro district adjacent to the south of the Mifuné area and classified their grain size distributions of bimodal curve into three major types. The representative of the sandstones of the Cretaceous Mifuné group is FuJI's A and B types. BoKman (1957) presented typical examples of bimodality in his study of the Stanley graywacke. Similar bimodality in grain size distribution is also reported in some Mesozoic and Paleozoic sandstones in Japan (Fujn, 1954; Mizutani, 1957). Meanwhile, Helmbold's detailed study of the classical Tanner graywacke of the Harz Mountains (Helmbold, 1952; Van HouteN [Translator], 1958) reveals that grain size distributions of the Tanner Traywacke are unimodal. Further, he noted that the term matrix may be a misnormer in that it implies a bimodal population. 
The relation between the mean size of quartz grains and its standard deviation is illustrated in Text-fig. 5.

(2) Roundness.-KRUMBEIN (1941) presented a visual chart for an estimate of roundness of grains, having graded it into ten classes. Following his scheme, the results obtained show that 19 percent of the samples examined falles in the class of $0.6,41$ percent in that of $0.5,30$ percent in that of 0.4 , and the rest only 10 percent is ranked at the class 0.3 .

One thing to be especially mentioned is that there seems to be some variation in horizontal distribution of roundness; in the northeastern part of the basin the average roundness of the grains is somewhat lower than that of the southwestern part, as is reviewed and commented elsewhere (p. 27, Text-fig. 16).

\section{Summary of sandstone patterns}

The lithologic type of the sandstones of the Mifune group belongs as a whole to the graywacke suite, according to the classification scheme of DAPPLEs et al. (1953) (see P1. 2, Figs. 1-8). Rather large

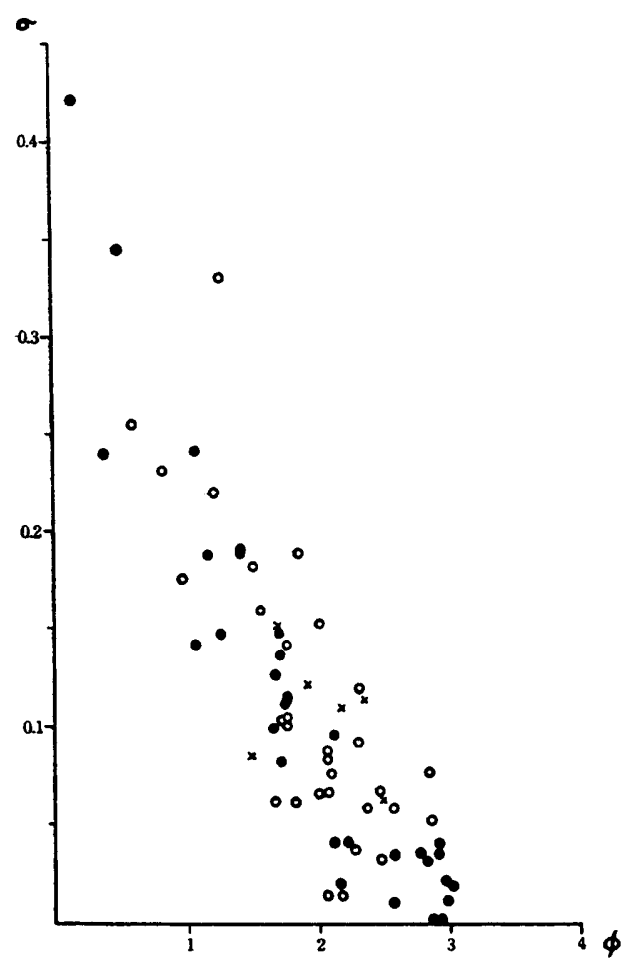

Fig. 5. Relation between mean size $(\phi)$ of quartz grains and their sorting $(\sigma)$. Explanation:

$x$ : Basal formation

$O$ : Lower formation

: Upper formation amount of their matrix makes it hard to give a pertinent application of PETTIJOHN's classification (Pettijohn, 1957). According to Fujir's scheme of classification (Fujn, 1955), about 40 percent of sandstone samples fall in the muddy quartzose sandstone, another 40 percent in the muddy feldspathic to subfeldspathic sandstone, and the rest 20 percent in the muddy lithic to sublithic sandstone.

Thus no remarkable distinctions of the lithologic types have taken place in accordance with stratigraphic order, as in the contemporaneous Goshonoura group (OKADA et al., 1960).

Besides, tuffaceous sandstone is another lithologic type, which is related with tuffite. Thus this type of sandstones is commented separately in another chapter (p. 21).

The mineral compositions of the individual sandstones examined are presented in Text-fig. 6. 


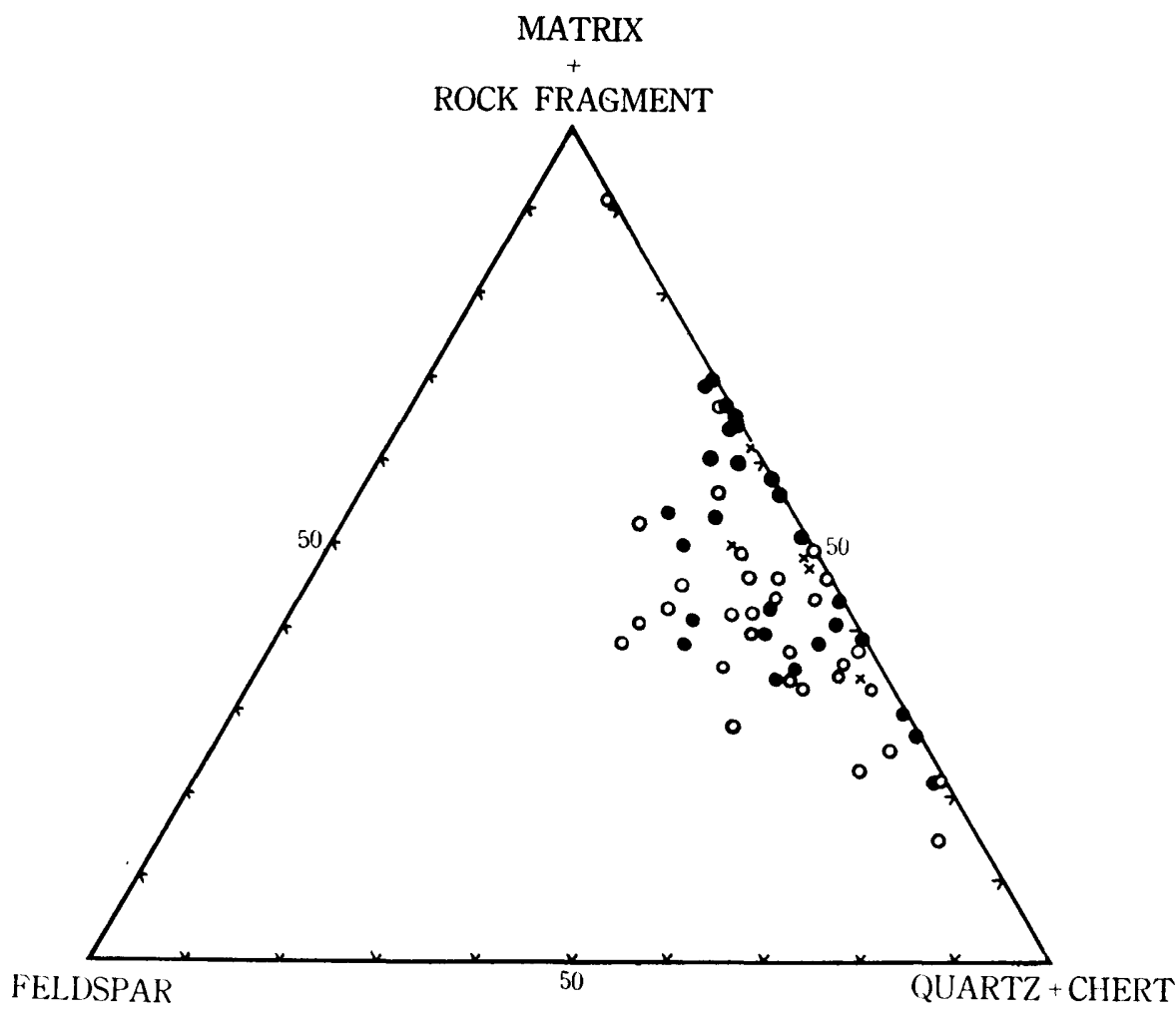

Fig. 6. Compositional diagram of sandstones.

Explanation:
$x$ : Basal formation
$O$ : Lower formation
: Upper formation

Table 2. Modal analyses

\begin{tabular}{|c|c|c|c|c|c|c|c|c|c|c|c|c|c|c|c|c|c|}
\hline \multirow[b]{2}{*}{$\underset{\text { No.† }}{\text { Sample }}$} & \multicolumn{3}{|c|}{ Quartz } & & \multicolumn{5}{|c|}{ Feldspar } & \multirow[b]{2}{*}{$\stackrel{\vec{J}}{\stackrel{0}{\circ}}$} & \multirow[b]{2}{*}{ 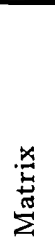 } & \multirow{2}{*}{ 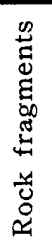 } & \multirow[b]{2}{*}{ 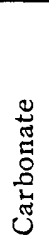 } & \multicolumn{3}{|c|}{ Size } & \multirow[b]{2}{*}{ 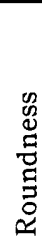 } \\
\hline & 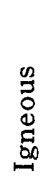 & 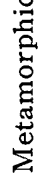 & $\stackrel{\pi}{0}$ & 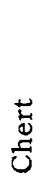 & 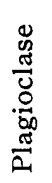 & 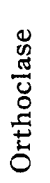 & م & 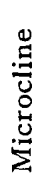 & 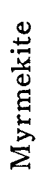 & & & & & 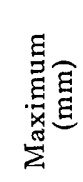 & 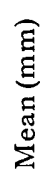 & 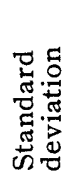 & \\
\hline 0017 & 28 & 17 & 45 & 4 & 3 & 1 & 1 & & & 5 & 43 & 3 & & .96 & .31 & .15 & .5 \\
\hline 0002 & 38 & 1 & 39 & 3 & 5 & 3 & $\operatorname{tr}$ & $\operatorname{tr}$ & $\operatorname{tr}$ & 8 & 49 & 1 & & .56 & .17 & .06 & .5 \\
\hline 0003 & 21 & 38 & 59 & 4 & 2 & 1 & $\operatorname{tr}$ & $\operatorname{tr}$ & $\operatorname{tr}$ & 3 & 32 & 2 & & 1.78 & .36 & .08 & .5 \\
\hline 0005 & 22 & 26 & 48 & 2 & 1 & 1 & & $\operatorname{tr}$ & $\operatorname{tr}$ & 2 & 46 & 2 & & 7.5 & .27 & .12 & .6 \\
\hline 0010 & 22 & 26 & 48 & 2 & 1 & 1 & $\operatorname{tr}$ & & $\operatorname{tr}$ & 2 & 47 & 1 & & .72 & .23 & .11 & .3 \\
\hline 0013 & 15 & 20 & 35 & 3 & $\operatorname{tr}$ & $\operatorname{tr}$ & & & & $\operatorname{tr}$ & 61 & 1 & & .77 & .19 & .11 & .4 \\
\hline 1001 & 17 & 45 & 62 & 2 & 2 & 1 & $\operatorname{tr}$ & tr & $\operatorname{tr}$ & 3 & 30 & 3 & & 1.36 & .33 & .16 & .4 \\
\hline 1003 & 20 & 53 & 73 & 5 & tr & $\operatorname{tr}$ & $\operatorname{tr}$ & & $\operatorname{tr}$ & $\operatorname{tr}$ & 20 & 2 & & 1.33 & .40 & & .3 \\
\hline 1005 & 21 & 34 & 55 & 5 & 3 & 2 & $\operatorname{tr}$ & & tr & 5 & 32 & 3 & & 1.26 & .47 & & .4 \\
\hline
\end{tabular}


Table 2. Continued.

\begin{tabular}{|c|c|c|c|c|c|c|c|c|c|c|c|c|c|c|c|c|c|}
\hline 1006 & & & 53 & & & & & & & 1 & 46 & & & .26 & .13 & .15 & .3 \\
\hline 1009 & 30 & 20 & 50 & 3 & 11 & 7 & $\operatorname{tr}$ & & 1 & 19 & 27 & 1 & & .77 & .20 & .12 & .6 \\
\hline 1011 & 24 & 23 & 47 & 2 & 7 & 4 & $\operatorname{tr}$ & & $\operatorname{tr}$ & 11 & 36 & $\operatorname{tr}$ & 4 & .56 & .20 & .09 & .4 \\
\hline 1012 & 20 & 20 & 40 & 6 & 9 & 4 & $\operatorname{tr}$ & $\operatorname{tr}$ & $\operatorname{tr}$ & 13 & 40 & 1 & & .48 & .17 & .03 & .4 \\
\hline 1013 & 21 & 15 & 36 & 3 & 11 & 5 & & & & 16 & 45 & & & .32 & .14 & .08 & .4 \\
\hline 1015 & 25 & 25 & 50 & & 1 & 1 & $\mathrm{tr}$ & & $\operatorname{tr}$ & 2 & 24 & 9 & 15 & .80 & .31 & .06 & .4 \\
\hline 1017 & 17 & 50 & 67 & 3 & $\operatorname{tr}$ & 1 & & & $\operatorname{tr}$ & 1 & 27 & & 3 & 2.24 & .63 & .26 & .3 \\
\hline 1018 & 27 & 31 & 58 & 3 & 1 & 1 & & & & 2 & 34 & 3 & & .56 & .21 & .04 & .3 \\
\hline 1020 & 27 & 17 & 44 & 5 & 4 & 4 & & $\operatorname{tr}$ & & 8 & 30 & 4 & 9 & .56 & .24 & .08 & .5 \\
\hline 1024 & 21 & 23 & 44 & 2 & 6 & 7 & $\operatorname{tr}$ & $\operatorname{tr}$ & $\operatorname{tr}$ & 13 & 40 & 1 & & .80 & .27 & .19 & .5 \\
\hline 1027 & 36 & 14 & 50 & 8 & 5 & 5 & $\operatorname{tr}$ & $\mathrm{tr}$ & $\operatorname{tr}$ & 10 & 32 & $\operatorname{tr}$ & & .48 & .22 & .01 & .5 \\
\hline 1028 & 26 & 20 & 46 & 14 & 2 & 2 & & & $\mathrm{tr}$ & 4 & 35 & 1 & & .72 & .23 & .08 & .5 \\
\hline 1029 & 40 & 19 & 59 & 11 & 2 & 2 & $\operatorname{tr}$ & & $\operatorname{tr}$ & 4 & 25 & 1 & & .72 & .28 & .06 & .6 \\
\hline 1030 & 24 & 14 & 38 & 10 & 4 & 7 & $\operatorname{tr}$ & & & 11 & 40 & 1 & & .96 & .35 & .18 & .5 \\
\hline 1031 & 29 & 12 & 41 & 8 & 4 & 3 & & & $\operatorname{tr}$ & 7 & 41 & 3 & & .53 & .23 & .01 & .5 \\
\hline 1032 & 32 & 17 & 49 & 8 & 6 & 6 & & $\operatorname{tr}$ & $\operatorname{tr}$ & 12 & 28 & 3 & & .77 & .29 & .11 & .5 \\
\hline 1037 & 30 & 10 & 40 & 6 & 5 & 4 & & & $\operatorname{tr}$ & 9 & 40 & 1 & 4 & .74 & .28 & .11 & .4 \\
\hline 1038 & 36 & 8 & 44 & 4 & 8 & 9 & & $\operatorname{tr}$ & $\operatorname{tr}$ & 17 & 30 & 2 & 3 & .75 & .29 & .10 & .5 \\
\hline 1042 & 35 & 13 & 48 & 6 & 3 & 6 & & & & 9 & 34 & 3 & & .38 & .17 & .06 & .5 \\
\hline 1056 & 26 & 25 & 51 & 3 & 1 & 2 & & & & 3 & 43 & $\operatorname{tr}$ & & .61 & .20 & .06 & .5 \\
\hline 1057 & 36 & 10 & 46 & 10 & 5 & 6 & & & $\operatorname{tr}$ & 11 & 30 & 3 & & .69 & .24 & .09 & .6 \\
\hline 1058 & 43 & 22 & 65 & 3 & 3 & 5 & $\operatorname{tr}$ & & $\operatorname{tr}$ & 9 & 22 & 1 & & 1.36 & .50 & .18 & .6 \\
\hline 1059 & 24 & 6 & 30 & 1 & 6 & 11 & $\operatorname{tr}$ & & $\operatorname{tr}$ & 17 & 49 & $\mathrm{tr}$ & 3 & .32 & .13 & .05 & .5 \\
\hline 1062 & 20 & 17 & 37 & 2 & 9 & 10 & $\operatorname{tr}$ & & $\operatorname{tr}$ & 19 & 33 & 1 & 8 & .58 & .22 & .07 & .5 \\
\hline 1063 & 22 & 9 & 31 & 5 & 8 & 18 & $\operatorname{tr}$ & & $\operatorname{tr}$ & 26 & 34 & 3 & 1 & .75 & .30 & .10 & .5 \\
\hline 1069 & 23 & 10 & 33 & 4 & 9 & 14 & $\operatorname{tr}$ & & $\operatorname{tr}$ & 23 & 35 & 1 & 4 & .56 & .23 & .09 & .5 \\
\hline 1071 & 16 & 18 & 34 & 3 & 2 & 5 & & & & 7 & 10 & 4 & 42 & .78 & .28 & .14 & .6 \\
\hline 2007 & 33 & 19 & 52 & 2 & 10 & 14 & 2 & $\operatorname{tr}$ & $\operatorname{tr}$ & 26 & 20 & & & .74 & .30 & .14 & .5 \\
\hline 2009 & 19 & 24 & 43 & 6 & 4 & 3 & 1 & & $\operatorname{tr}$ & 8 & 35 & 8 & & 1.20 & .37 & .19 & .5 \\
\hline 2010 & 18 & 54 & 72 & 8 & 3 & 2 & & & & 5 & 13 & 2 & & 1.09 & .44 & .19 & .5 \\
\hline 2013 & 11 & 23 & 34 & 8 & $\operatorname{tr}$ & $\mathrm{tr}$ & & & & $\operatorname{tr}$ & 55 & 3 & & 1.49 & .25 & .15 & .4 \\
\hline 2015 & & & 22 & 7 & & & & & & 2 & 69 & & & .27 & .13 & .02 & .3 \\
\hline$\dagger+2018$ & 15 & 16 & 31 & 2 & $\operatorname{tr}$ & $\operatorname{tr}$ & & & & 1 & 67 & & & .40 & .14 & .02 & .3 \\
\hline 2021 & 9 & 50 & 59 & 2 & $\operatorname{tr}$ & $\operatorname{tr}$ & & & & $\operatorname{tr}$ & 36 & & 3 & 1.98 & .71 & .35 & .4 \\
\hline 2022 & 19 & 15 & 34 & $\operatorname{tr}$ & 1 & 1 & & & $\operatorname{tr}$ & 2 & 62 & $\operatorname{tr}$ & 2 & .48 & .17 & .04 & .5 \\
\hline 2026 & 11 & 37 & 48 & 8 & $\operatorname{tr}$ & $\operatorname{tr}$ & & & & $\operatorname{tr}$ & 42 & 2 & & 1.50 & .47 & .24 & .4 \\
\hline 2033 & & & 32 & 2 & & & & & & 1 & 65 & & & .24 & .12 & .01 & .3 \\
\hline 2046 & 25 & 32 & 57 & & 1 & 2 & & & $\operatorname{tr}$ & 3 & 38 & & 2 & .32 & .13 & .04 & .4 \\
\hline
\end{tabular}


Table 2. Continued.

\begin{tabular}{|c|c|c|c|c|c|c|c|c|c|c|c|c|c|c|c|c|}
\hline 2048 & 16 & 17 & 33 & 2 & $\operatorname{tr}$ & $\operatorname{tr}$ & $\operatorname{tr}$ & & & 1 & 64 & & & .46 & .14 & .04 \\
\hline 2050 & 12 & 55 & 67 & 5 & 1 & $\operatorname{tr}$ & & & & 1 & 27 & & & 1.92 & .78 & .24 \\
\hline 2051 & 17 & 18 & 35 & 2 & 2 & 1 & $\operatorname{tr}$ & $\operatorname{tr}$ & $\operatorname{tr}$ & 3 & 56 & 1 & 3 & .56 & .22 & .04 \\
\hline 2064 & 12 & 10 & 22 & & 6 & 5 & & & $\operatorname{tr}$ & 11 & 67 & & & .32 & 13. & .01 \\
\hline 2077 & 17 & 16 & 33 & $\mathrm{tr}$ & 1 & $\operatorname{tr}$ & & & & 1 & 58 & $\operatorname{tr}$ & 7 & .40 & .14 & .03 \\
\hline 2082 & 14 & 15 & 29 & 2 & 7 & 7 & & & $\operatorname{tr}$ & 14 & 33 & 3 & 19 & .66 & .23 & .10 \\
\hline 2090 & 35 & 15 & 50 & 5 & 5 & 4 & 1 & & & 10 & 23 & 3 & 9 & .72 & .31 & .10 \\
\hline 2092 & 23 & 48 & 71 & 6 & 1 & $\mathrm{tr}$ & & & & 1 & 22 & & & .67 & .29 & .11 \\
\hline 2095 & & & 29 & $\mathrm{tr}$ & & & & & & 1 & 70 & $\operatorname{tr}$ & & .19 & .12 & .02 \\
\hline 2096 & 20 & 26 & 46 & 4 & $\operatorname{tr}$ & $\operatorname{tr}$ & & & & $\operatorname{tr}$ & 48 & 2 & & .62 & .18 & .07 \\
\hline 2097 & 22 & 20 & 42 & 1 & $\operatorname{tr}$ & 1 & & & & 1 & 56 & $\operatorname{tr}$ & & .35 & .13 & .04 \\
\hline 2099 & 23 & 29 & 52 & 4 & & & & & & 6 & 11 & 27 & & 2.08 & .92 & .42 \\
\hline 2100 & 22 & 23 & 45 & 3 & 1 & $\mathrm{tr}$ & & & $\operatorname{tr}$ & 1 & 50 & $\operatorname{tr}$ & & .45 & .15 & .04 \\
\hline 2102 & 11 & 27 & 38 & 4 & 7 & 2 & & & & 9 & 47 & 2 & & 1.28 & .47 & .14 \\
\hline 2104 & 31 & 10 & 41 & $\operatorname{tr}$ & 9 & 9 & & & $\operatorname{tr}$ & 18 & 40 & 1 & & .50 & .23 & .04 \\
\hline 2106 & 30 & 12 & 42 & $\mathrm{tr}$ & 10 & 9 & $\operatorname{tr}$ & & $\operatorname{tr}$ & 19 & 37 & 1 & & .74 & .31 & .08 \\
\hline 2124 & 15 & 18 & 33 & 1 & 5 & 1 & & & & 6 & 53 & 2 & 5 & .61 & .31 & .13 \\
\hline 2126 & 25 & 8 & 33 & 1 & 7 & 5 & $\operatorname{tr}$ & 1 & & 13 & 47 & & 6 & .51 & .17 & .01 \\
\hline 2145 & 29 & 11 & 40 & 7 & 7 & 3 & 1 & & $\operatorname{tr}$ & 11 & 40 & 2 & & 1.23 & .37 & .19 \\
\hline 2146 & 11 & 14 & 25 & 4 & 4 & 4 & & & & 8 & 51 & 2 & 10 & .67 & .23 & .02 \\
\hline 2150 & 26 & 24 & 50 & 4 & 8 & 3 & 1 & $\operatorname{tr}$ & $\operatorname{tr}$ & 12 & 31 & 3 & & 1.04 & .42 & .15 \\
\hline
\end{tabular}

$\dagger$ MF. 0017: from the northern wing of the Basal formation of the Mifune group.

MF. 0002-0013: from the southern wing of the ditto.

MF. 1001-1015: from the northern wing of the Lower formation.

MF. 1017-1071: from the southern wing of the ditto.

MF. 2007-2150: from the Upper formation.

† Presenting red-tinted appearance.

\section{Mineral composition}

\section{a. Major constituents}

(1) Quartz.-Detrital quartz is the predominant constituent of the Mifuné group, varying in amount from 30 percent to 72 percent. Quartz varieties are discriminated by almost the same method used by Potter and Siever (1956, p. 318), dividing the grains into two groups, although the metamorphic quartzite is included in the category of metamorphic quartz. Basically these depend upon the grouping of varieties described by KRYNINE (1940) and WEAVER (1955). FuJII (1958) also discriminated four varieties of quartz grains, among which cryptocrystalline quartz (or WEAvER's microcrystalline quartz) is described under the component of chert in this paper.

Igneous quartz stands for all the grains which have no or only mild strain shadows. In the group of metamorphic quartz are placed both monocrystalline and 
polycrystalline grains which show extremely undulose extinction (Pl. 2, Figs. 1, 3, 4).

The two types of quartz are both found in all of the samples of the Mifuné group.

Horizontal distributions of each of them are rather significant, as is stated in another chapter (p. 27).

(2) Feldspar.-The feldspar grains are considerably small in amount, presenting, on the average, 3 percent in the Basal formation, 9 percent in the Lower formation, and 6 percent in the Upper formation. They are subangular, being in general somewhat more angular than the quartz.

Most of the feldspar grains are plagioclase and orthoclase. Very few grains of perthite and microcline together with myrmekite are sporadically observed throughout the basin. Plagioclase feldspar varies from labradorite to andesine in nature.

Many of the feldspar grains are fresh in appearance. Replacement by carbonates is not common.

CROWLEY (1939) examined feldspar in marine and non-marine sediments, regarding the presence of authigenic feldspar to be a possible criterion of marine origin. No feldspar grains at hand, however, are identified easily with such an authigenic feature.

According to FujII (1956), quantity of feldspar from the Lower Cretaceous
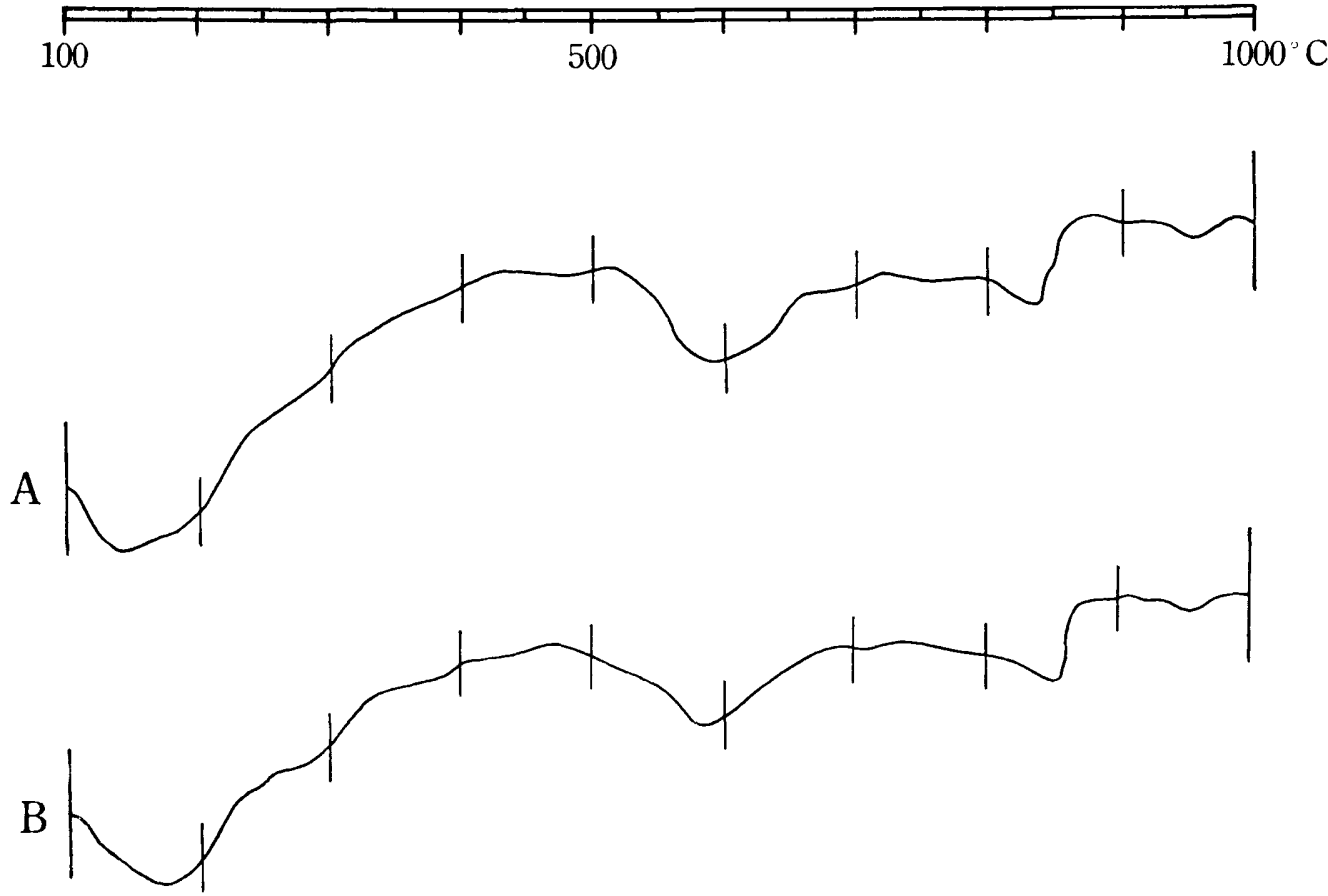

Fig. 7. Data of differential thermal analysis of selected samples of greenish sediments.

A : medium-grained sandstone, Sp. No. MF. Ex. 3

B: fine-rained sandstone, Sp. No. MF. 2071 
Kawaguchi formation is in verse proportion to the mean size of the quartz grains. SHIKI (1958) also recognizes such a tendency in the Triassic sandstones in the Maizuru belt. Yet there are no definite relations between them in the Mifuné group.

(3) Rock fragments.-Common components are of chert, schists, volcanic rocks, and slate. For convenience, however, chert grains are included in the quart $z$ clan in some parts of this paper.

i) Chert; Chert fragments are almost synonimous with microcrystalline quartz or cryptocrystalline quartz (WEAVER, 1955; FuJI, 1958), including chalcedonic quartz (Folk et al., 1952). Under the microscope such a type of quartz occurs as tightly packed grains of quartz, varying in size from less than 1 to 60 microns in diameter.

The detrital chert grains are present in almost all the specimens examined, although they do not exceed over 10 percent in amount. They are usually better rounded than the quartz. Sericite or illite-like shreds are frequently found as inclusions in the chert grains; they are unoriented.

No fossil remains are traced.

ii) Volcanic rocks; They exhibit intersertal and/or hyalopilitic textures, being more or less altered.

iii) Schists; Fragments of schists are commonly met with especially in con-

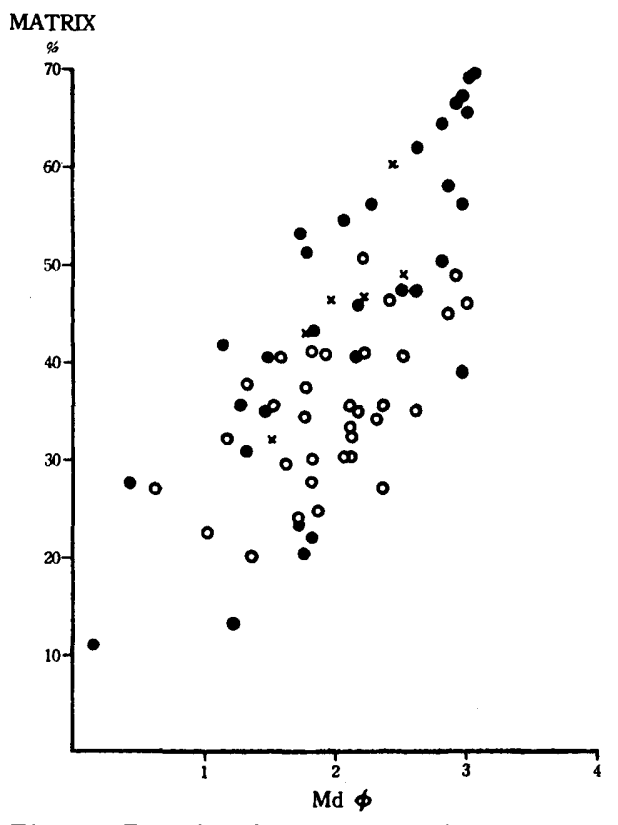

Fig. 8. Retation between matrix percen. tage and mean size of quartz grains. Explanation:

$x$ : Basal formation

$O$ : Lower formation

: Upper formation glomerate.

(4) Matrix. - In most cases mechanical analysis of the thin-sections gives, on the average, about 40 percent for matrix. This value is very high. Detrital grains smaller than two microns in diameter are included in the matrix. Special mention to be extended is the red matrix in the redtinted sandstones prominent in the Basal und Upper formations, although their occurrence is very limited; the slides show nearly all the grains coated with red opaque iron oxide. Neither D.T.A. nor X-ray analysis of red shale has shown any significant results probably because of its impurities.

Another to be noted is the matrix of greenish sandstones which are predominant especially in the Upper formation, and also in the Lower formation. The D.T.A. data indicate the preponderance of chloritic minerals, although their exact identification 
is rather difficult due to impurities of the samples examined (Text-fig. 7).

Quantity of matrix is inversely proportional to the grain size (Text-fig. 8).

(5) Chemical cement.-The chemical cement of calcite fills up the pore of some restricted sandstones, varying from 2 to 9 percent in amount; in one case it obtains 42 percent (Sp. No. MF. 1071). It occurs as fine-grained bobs or rhomb of calcite, more or less penetrating and coroding the quartz and/or feldspar grains.

Silica cement is also sometimes met with.

\section{b. Heavy minerals}

Heavy minerals identified in the sandstones of the Mifuné group are mainly as follows: epidote, zircon, garnet, tourmaline, chlorite, muscovite, biotite, augite, hornblende, rutile, titanite, anatase, and glaucophane, together with iron opaques of hematite, pyrite, and magnetite or ilmenite. Among them, epidote is most prevalent and can be regarded as an index mineral of the Mifuné group. Heavy mineral components are tabulated in Table 3.

Table 3. Heavy mineral assemblages

\begin{tabular}{|c|c|c|c|c|c|c|c|c|c|c|c|c|c|c|c|c|c|c|c|c|c|c|c|}
\hline$\underset{\text { No.† }}{\text { Sample }}$ & 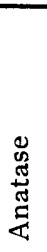 & 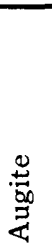 & 莒 & 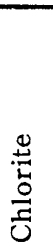 & $\begin{array}{l}\stackrel{0}{\circ} \\
\stackrel{0}{0} \\
\stackrel{0}{0} \\
\text { I }\end{array}$ & $\begin{array}{l}\mathrm{G} \\
\frac{0}{2} \\
\frac{1}{5} \\
\frac{0}{2} \\
\frac{0}{2}\end{array}$ & 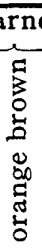 & $\begin{array}{l}\frac{n}{0} \\
\frac{2}{2} \\
\frac{2}{2} \\
\frac{0}{8}\end{array}$ & 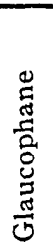 & 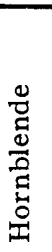 & 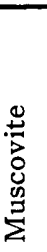 & $\stackrel{0}{\stackrel{\Xi}{ت ٍ ~}}$ & 总 & 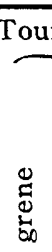 & $\begin{array}{l}5 \\
5 \\
5 \\
5\end{array}$ & $\stackrel{9}{\Xi}$ & 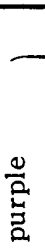 & 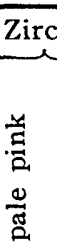 & $\frac{0}{0}$ & $\stackrel{3}{\frac{3}{0}}$ & 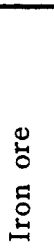 & 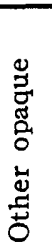 & 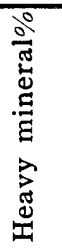 \\
\hline 0016 & & & & 2 & 1 & & & & & & & 1 & & 10 & 1 & 3 & 2 & & 7 & & 30 & 43 & 0.21 \\
\hline 0017 & & 3 & 1 & 1 & 4 & 2 & 4 & & & & 1 & 1 & & 4 & 2 & 1 & 1 & & 4 & & 54 & 17 & \\
\hline 0003 & & 2 & & & 18 & 3 & 1 & 2 & & 1 & $\operatorname{tr}$ & & & 1 & 2 & $\operatorname{tr}$ & 3 & & 2 & & 25 & 40 & 0.68 \\
\hline 0004 & & & & 1 & 13 & 2 & & & & & 1 & & & & 2 & 1 & & & 1 & & 41 & 38 & \\
\hline 0005 & & & $\operatorname{tr}$ & $\mathrm{tr}$ & 19 & 6 & $\operatorname{tr}$ & $\operatorname{tr}$ & & & & & ' & $\operatorname{tr}$ & $\operatorname{tr}$ & & 2 & & 8 & & 46 & 19 & 1.15 \\
\hline$\dagger 0006$ & & & 1 & & 1 & & & & & & & & & 1 & 2 & & 2 & 12 & 2 & & 73 & 7 & \\
\hline 0008 & & 2 & 1 & & 17 & 1 & 1 & 3 & & & & & & 4 & 3 & 1 & 1 & & 5 & & 36 & 24 & \\
\hline 0010 & $\operatorname{tr}$ & 3 & 1 & & 9 & 3 & 1 & 2 & & & & & & 3 & 2 & $\operatorname{tr}$ & 4 & & 3 & & 53 & 7 & 0.63 \\
\hline 0011 & $\operatorname{tr}$ & 3 & & & 14 & 1 & $\operatorname{tr}$ & 1 & & & & & & 3 & 1 & 2 & 1 & & 3 & & 20 & 50 & 0.08 \\
\hline 1001 & & 5 & 2 & 11 & 16 & $\operatorname{tr}$ & $\operatorname{tr}$ & & & & 2 & $\operatorname{tr}$ & & & & & & 2 & & & 11 & 53 & \\
\hline 1002 & & $\operatorname{tr}$ & 1 & 22 & 2 & & & & & 1 & 1 & & & 1 & & & & $\operatorname{tr}$ & & & 16 & 56 & \\
\hline 1003 & & $\operatorname{tr}$ & 1 & 15 & 11 & $\operatorname{tr}$ & $\operatorname{tr}$ & 1 & & & 3 & & & $\operatorname{tr}$ & & & & 2 & & & 10 & 56 & 0.95 \\
\hline 1005 & & 2 & $\operatorname{tr}$ & 17 & 12 & & & 1 & & $\operatorname{tr}$ & 5 & & & & & & & 1 & & & 11 & 51 & 0.62 \\
\hline 1006 & & 1 & $\operatorname{tr}$ & 13 & 7 & & & & & & 8 & & & & 1 & & & 1 & & 1 & 16 & 52 & 0.78 \\
\hline 1009 & & 2 & 1 & 6 & 8 & 1 & 1 & 1 & & & 1 & & & & & & & 1 & 1 & & 4 & 73 & 1.55 \\
\hline 1011 & & 2 & 2 & 8 & 11 & & & 3 & & 2 & 2 & & & tr & 2 & & & 1 & & & 10 & 57 & 0.84 \\
\hline 1012 & & 3 & 2 & 9 & 11 & & & 2 & & & 1 & & & 1 & 1 & & & 1 & & & 10 & 59 & 0.01 \\
\hline 1013 & & & 1 & 10 & 13 & 2 & 1 & 2 & & & 1 & & & & & & & 1 & & & 7 & 62 & 0.05 \\
\hline
\end{tabular}


Table 3. Continued.

\begin{tabular}{|c|c|c|c|c|c|c|c|c|c|c|c|c|c|c|c|c|c|c|c|c|c|}
\hline 1015 & 2 & 2 & 1 & 40 & 1 & 1 & 6 & & & & & & 1 & & $\operatorname{tr}$ & 1 & & & 13 & 32 & 3.00 \\
\hline 1018 & & & 12 & 11 & 1 & & & & 16 & & & & & & & 1 & 1 & & 28 & 29 & 4.25 \\
\hline 1020 & & & 16 & 28 & 17 & & 1 & & 1 & & & & & & 1 & 4 & & & 20 & 11 & 1.17 \\
\hline 1027 & & & 3 & 39 & 3 & $\operatorname{tr}$ & $\operatorname{tr}$ & $\operatorname{tr}$ & & & & & & & & 1 & 1 & & 9 & 44 & \\
\hline 1028 & & $\operatorname{tr}$ & 5 & 43 & 1 & $\operatorname{tr}$ & $\operatorname{tr}$ & & $\operatorname{tr}$ & & & & & & & 1 & 1 & & 11 & 38 & \\
\hline 1029 & & & 14 & 2 & 10 & 1 & 1 & 1 & 5 & & & & & & 1 & 12 & 1 & & 18 & 34 & \\
\hline 1030 & & & 24 & 4 & 20 & 1 & 1 & 1 & 1 & & & & & & 1 & 10 & & & 14 & 22 & 0.08 \\
\hline 1031 & & $\operatorname{tr}$ & 1 & 39 & 2 & & & & & & & & & & & 3 & & & 4 & 51 & 1.29 \\
\hline 1032 & & & 6 & 37 & 5 & 1 & $\operatorname{tr}$ & $\operatorname{tr}$ & & & & & & & & 2 & 1 & & 9 & 38 & 0.06 \\
\hline 1036 & & & 18 & 3 & 16 & $\operatorname{tr}$ & $\operatorname{tr}$ & & & & & & & & & 11 & $\operatorname{tr}$ & & 19 & 32 & 0.08 \\
\hline 1037 & & & 17 & 1 & 21 & 1 & & & & & & & & & 1 & 8 & & & 27 & 22 & \\
\hline 1038 & & 1 & 10 & 4 & 17 & $\operatorname{tr}$ & $\operatorname{tr}$ & & & & & & & & 1 & 4 & $\operatorname{tr}$ & & 35 & 27 & 0.78 \\
\hline 1042 & & 1 & 1 & 25 & 3 & 1 & 3 & & 1 & & & 1 & 3 & & & 2 & 2 & & 11 & 46 & 1.22 \\
\hline 1049 & 12 & & 1 & 24 & 1 & 2 & 4 & & & & & 2 & & & $\operatorname{tr}$ & 1 & 3 & & 20 & 29 & .49 \\
\hline 1050 & 7 & 1 & 1 & 15 & 6 & 4 & 2 & & & & & & & & & 8 & 2 & & 40 & 14 & .21 \\
\hline 1053 & 8 & & 1 & 20 & 2 & 1 & 2 & & 1 & & & 1 & 2 & & & 4 & & & 20 & 38 & \\
\hline 1054 & 12 & & & 23 & 2 & 1 & 3 & & & & & & & & & 2 & & & 5 & 52 & \\
\hline 1056 & & & 3 & 30 & & 1 & 2 & 2 & 2 & & & 1 & 2 & & & 1 & 1 & 1 & 14 & 40 & \\
\hline 2002 & 3 & & 1 & 29 & & & 1 & 1 & & & & 1 & & & & 1 & $\mathrm{tr}$ & 1 & 26 & 36 & \\
\hline 2003 & 1 & 6 & 4 & 19 & 1 & & 1 & & 1 & & & 1 & & & & 1 & & & 19 & 46 & 0.37 \\
\hline †2012 & 1 & & & 7 & 1 & & 1 & & & & & 1 & 1 & & & 1 & 1 & 1 & 72 & 13 & 0.10 \\
\hline 2013 & & & & 35 & & & 3 & & & & & & 1 & & & 4 & & & 34 & 23 & 0.22 \\
\hline$\dagger+2018$ & & 1 & & 7 & 1 & & & & 1 & & & 5 & 1 & & & 1 & & & 83 & & 2.55 \\
\hline 2022 & & & & & 4 & 1 & 2 & & & & & & & & & 17 & 2 & 2 & 28 & 44 & 0.29 \\
\hline 2026 & & 12 & & 6 & 2 & 1 & & 1 & & & & & & & & 25 & & 1 & 41 & 7 & 0.12 \\
\hline 2033 & 1 & & & 33 & & & & & & & & 1 & 1 & 1 & & 3 & & & 30 & 30 & 2.57 \\
\hline 2046 & 2 & & & 46 & 2 & & & & & & & 1 & $\operatorname{tr}$ & & & 3 & & & 14 & 32 & 1.74 \\
\hline 2050 & 1 & 1 & & 20 & 1 & & 1 & & & & & 1 & & & & 11 & & & 47 & 17 & 0.15 \\
\hline 2077 & 13 & 1 & 2 & 28 & & 1 & 1 & & 1 & & & 2 & 1 & & & & 2 & & 19 & 29 & 2.45 \\
\hline 2080 & 3 & & 1 & 42 & 1 & & 1 & & 1 & & & & & & & 2 & & & 37 & 12 & \\
\hline 2082 & 12 & & 3 & 25 & 1 & 2 & & & & & & 1 & & & 1 & & 3 & & 18 & 341 & 11.57 \\
\hline 2090 & 4 & 2 & 7 & 51 & 6 & 1 & 2 & 1 & 1 & & & & 1 & 1 & $\operatorname{tr}$ & 3 & 1 & & 9 & 10 & 0.44 \\
\hline 2092 & 1 & $\operatorname{tr}$ & 2 & 8 & 1 & & & & & $\operatorname{tr}$ & & & 2 & & & 6 & $\operatorname{tr}$ & & 28 & 52 & \\
\hline+2093 & & & 4 & 3 & 1 & & & & & & & 1 & 1 & & & 1 & & & 75 & 14 & \\
\hline 2094 & & 6 & 3 & 20 & 1 & $\mathrm{tr}$ & $\operatorname{tr}$ & 1 & & & & $\operatorname{tr}$ & $\operatorname{tr}$ & & 1 & 4 & $\operatorname{tr}$ & & 20 & 44 & \\
\hline 2095 & & $\operatorname{tr}$ & 2 & 29 & $\operatorname{tr}$ & & $\operatorname{tr}$ & $\operatorname{tr}$ & & & $\operatorname{tr}$ & 1 & 1 & & & 3 & & & 22 & 42 & 0.29 \\
\hline 2096 & & $\operatorname{tr}$ & 1 & 22 & 2 & & $\operatorname{tr}$ & & $\operatorname{tr}$ & $\mathrm{tr}$ & & $\operatorname{tr}$ & $\operatorname{tr}$ & & 1 & 9 & $\operatorname{tr}$ & & 27 & 40 & \\
\hline 2097 & 2 & 1 & 1 & 13 & 1 & 1 & 1 & & 1 & 1 & & 2 & 2 & & $\operatorname{tr}$ & & 3 & & 28 & 43 & 0.11 \\
\hline
\end{tabular}


Table 3. Continued.

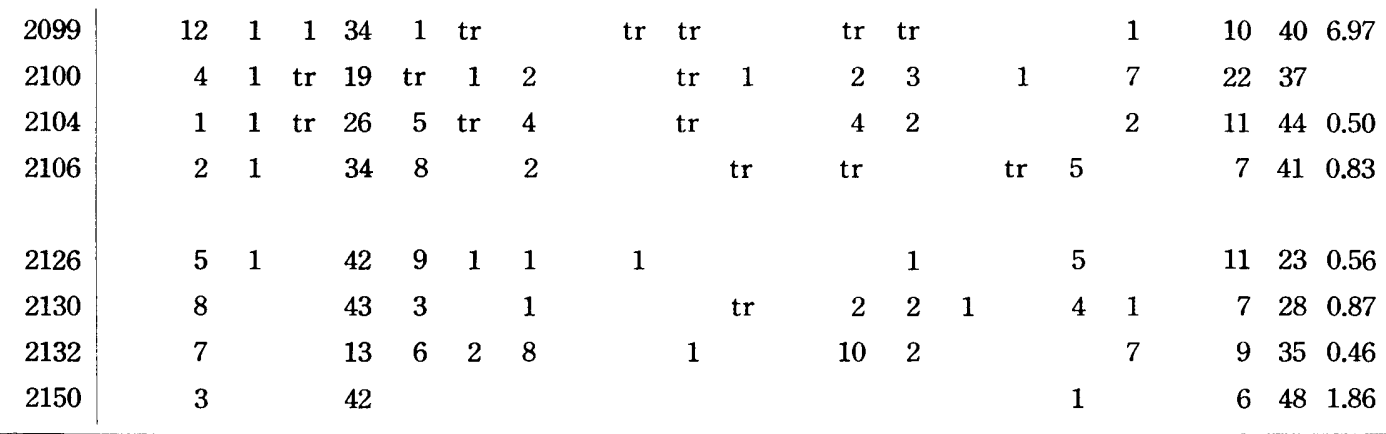

$\dagger$ MF. 0016-0017: from the northern wing of the Basal formation.

MF. 0003-0011: from the southern wing of the ditto.

MF. 1001-1051: from the northern wing of the Lower formation.

MF. 1018-1056: from the southern wing of the ditto.

MF. 2002-2150: from the Upper formation.

t† Presenting red-tinted appearance.

In the following, descriptions of selected heavy minerals are given in the order of abundance:

(1) Epidote.-This is the most important constituent. It occurs most abundantly throughout the basin as rounded crystals or angular pieces, being most prevalently yellowish green in color, sometimes colorless, and very rarely pinkish-tinted (Sp. No. MF. 1057). Most of the grains present a fresh appearance. The colored epidote shows more or less distinct paleochroism; $\mathrm{Y}=$ yellowish green, $\mathrm{Z}$ or $\mathrm{X}=$ colorless to less yellowish green. The datum of its $\mathrm{X}$-ray analysis is given in Table 4.

Table 4. X-ray data of epidote* from the sandstones of the Upper formation

\begin{tabular}{|c|c|c|c|c|c|c|c|c|}
\hline $\mathrm{d}(\AA \AA \AA)$ & I & & $\mathrm{d}(\AA)$ & I & & $\mathrm{d}(\mathrm{A})$ & I & \\
\hline 5.03 & 1 & $\mathrm{E}$ & 2.16 & 4 & $E$ & 1.624 & $1 / 2$ & \\
\hline 4.00 & 4 & $\mathrm{E}$ & 2.11 & 4 & $\mathrm{E}$ & 1.576 & $1 / 2$ & $\mathrm{E}$ \\
\hline 3.49 & 4 & & 2.06 & 2 & $\mathrm{E}$ & 1.538 & 1 & $\mathrm{E}$ \\
\hline 3.35 & 5 & $\mathbf{Q}$ & 2.04 & 1 & $\mathrm{E}$ & 1.506 & $I / 2$ & $\mathrm{E}$ \\
\hline 3.18 & 4 & & 2.00 & $1 / 2$ & & 1.452 & 5 & $\mathrm{E}$ \\
\hline 2.90 & 10 & $\mathrm{E}$ & 1.869 & 5 & $\mathrm{E}$ & 1.433 & $1 / 2$ & $\mathrm{E}$ \\
\hline 2.80 & 2 & $\mathrm{E}$ & 1.812 & $1 / 2$ & & 1.404 & $31 / 2$ & $\mathrm{E}$ \\
\hline 2.66 & 7 & $\mathrm{E}$ & 1.768 & $1 / 2$ & & 1.389 & $31 / 2$ & $\mathrm{E}$ \\
\hline 2.58 & 5 & $\mathrm{E}$ & 1.740 & $1 / 2$ & & 1.369 & $1 / 2$ & \\
\hline 2.52 & 3 & $\mathrm{E}$ & 1.696 & $1 / 2$ & & 1.343 & $1 / 2$ & $\mathrm{E}$ \\
\hline 2.45 & 2 & $\mathrm{E}$ & 1.683 & $1 / 2$ & & 1.323 & $1 / 2$ & \\
\hline 2.39 & 7 & $\mathrm{E}$ & 1.663 & $1 / 2$ & & 1.297 & 1 & $\mathrm{E}$ \\
\hline 2.29 & 3 & $\mathrm{E}$ & 1.631 & 8 & $\mathrm{E}$ & 1.262 & 1 & $\mathrm{E}$ \\
\hline
\end{tabular}

Note: Camera radius $57.3 \mathrm{~mm}$.

$\mathrm{FeK}_{\alpha}$ radiation.

E: Epidote

Q: Quartz

* Separated from the specimens of MF. 2013, 2046, 2080, 2090, and 2130. 
(2) Zircon.-This occurs in all of the specimens as a very common mineral. It is subdivided into four varieties according to its colors through transmitted light: colorless, pale pink, yellow, and purple varieties. Among them the former two are of common occurrence throughout the formations, whereas the purple zircon is very characteristic in the Basal formation. The yellow one is rarely detected.

As to the roundness, colorless and pale pink zircon grains indicate usually an unworn idiomorph, although some are to a certain extent abraded. The pale pink zircon is more frequently modified by abrasion than the colorless one. On the other hand, purple zircon is in general exceedingly well rounded (Pl. 4, Figs.3-7; Pl. 5, Fig. 7), but exceptionally a very limited amount of euhedral purple zircon is decernible. The roundness of zircon grains is highest in the Basal formation (Textfig. 9).

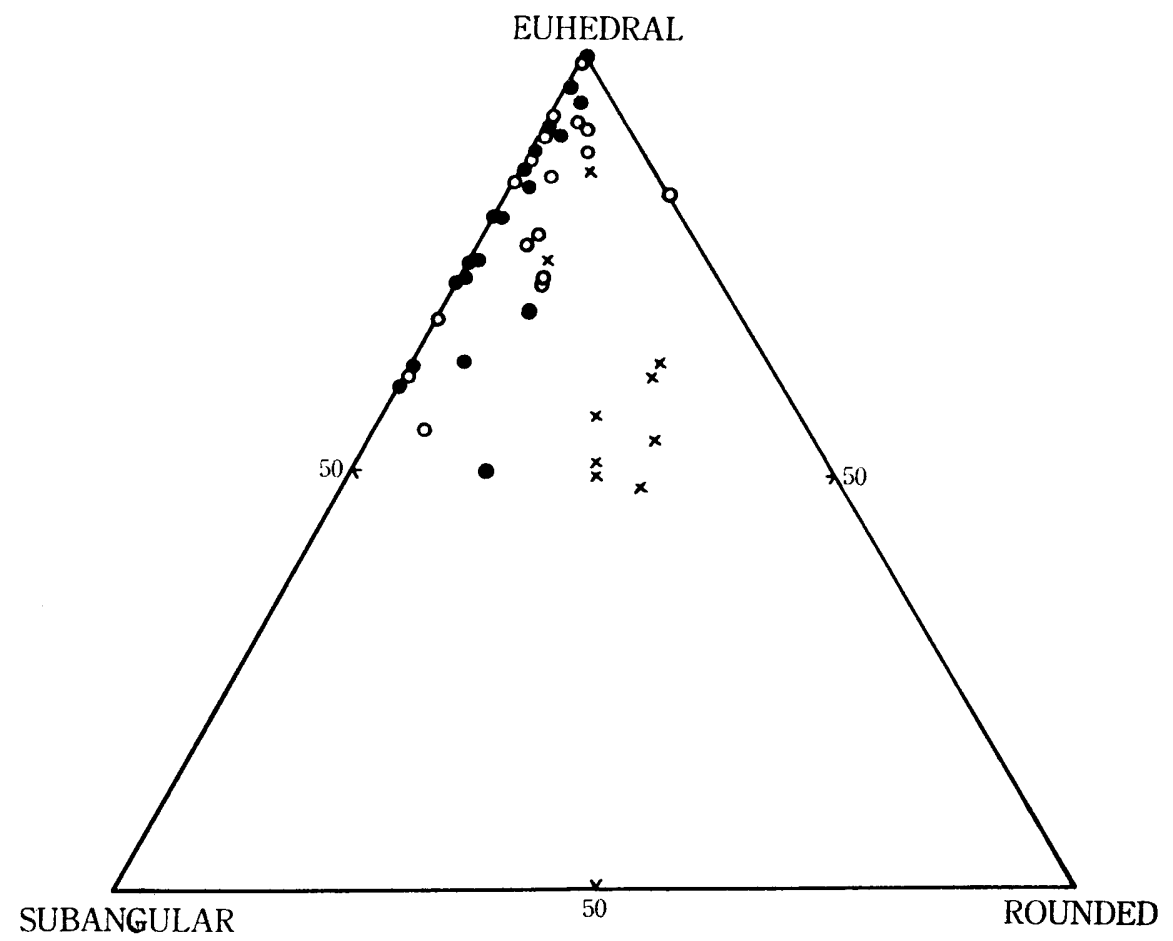

Fig. 9. Roundness-ratio of zircon grains of sandstones.

\section{Explanation :}

$x$ : Basal formation $O$ : Lower formation $\quad$ : Upper formation

According to KARAKIDA's scheme of classification (KARAKIDA, 1954), crystal habits of zircon are classified into three major types, S, D, and C. Zircon of type C with bipyramidal terminations is prevalent in the Mifuné group (Text-fig. 10).

In the unworn grains of the euhedral zircon they have the elongation ratio of 1.5 to 3 , but sometimes have that of 4 or even more. As is illustrated in Textfigs. 11,12 , and 13 , the euhedral zircon tends to show a definite ratio in each forma- 


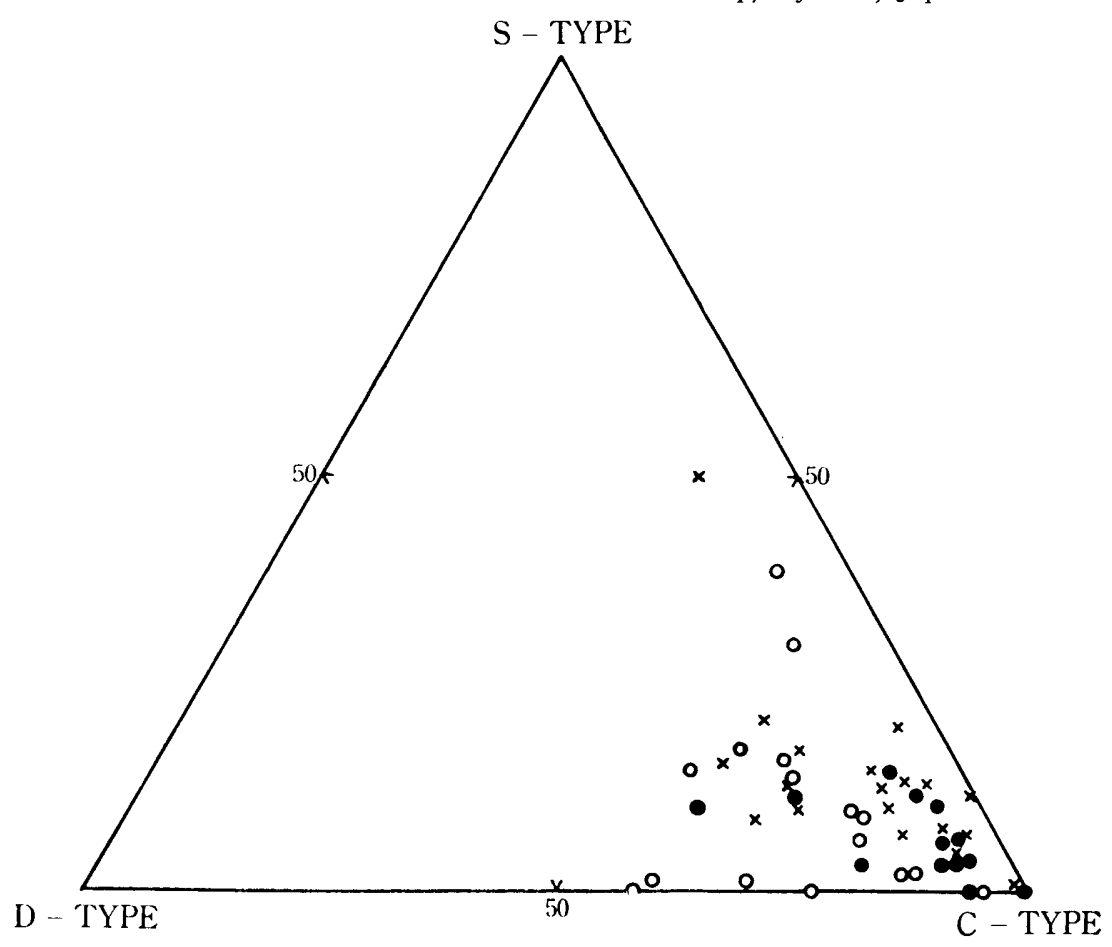

Fig. 10. Zircon Tracht diagram of sandstones.

Explanation: $\times$ : Basal formation $O$ : Lower formatioc $O$ : Upper formation
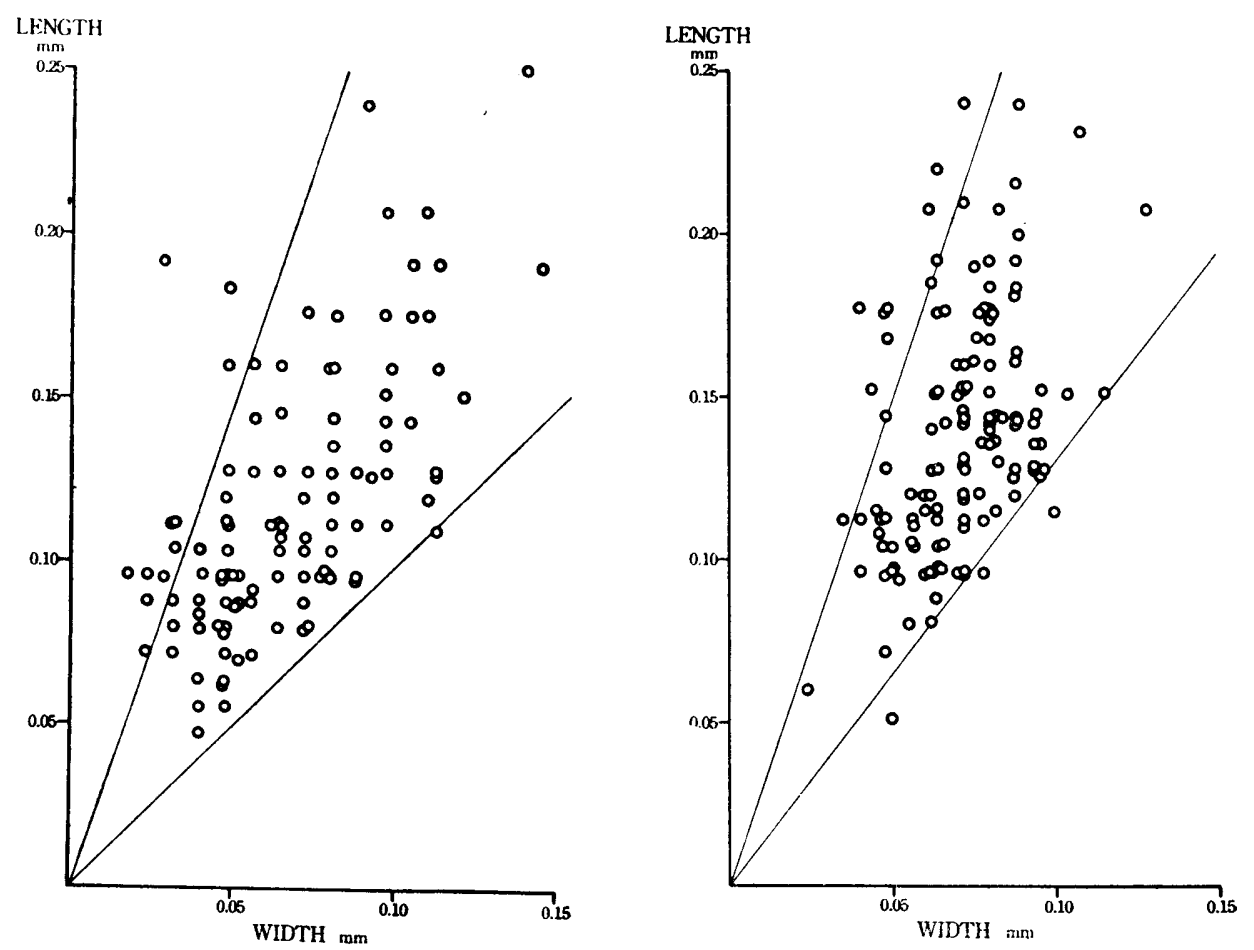

Fig. 11. Elongation diagram of zircon grains. Fig. 12. Elongation diagram of zircon grains. Sandstones of the Basal formation.

Sandstones of the Lower formation. 


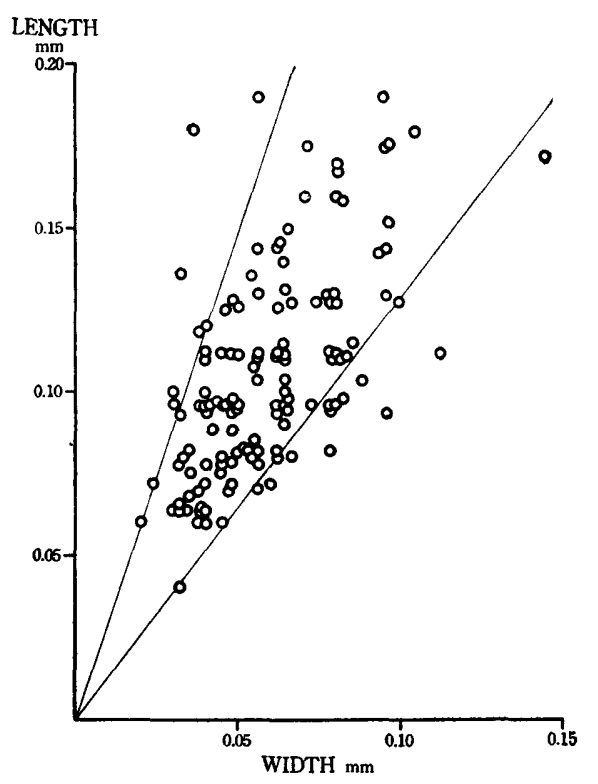

Fig. 13. Elongation diagram of zircon grains. Sandstones of the Upper formation.

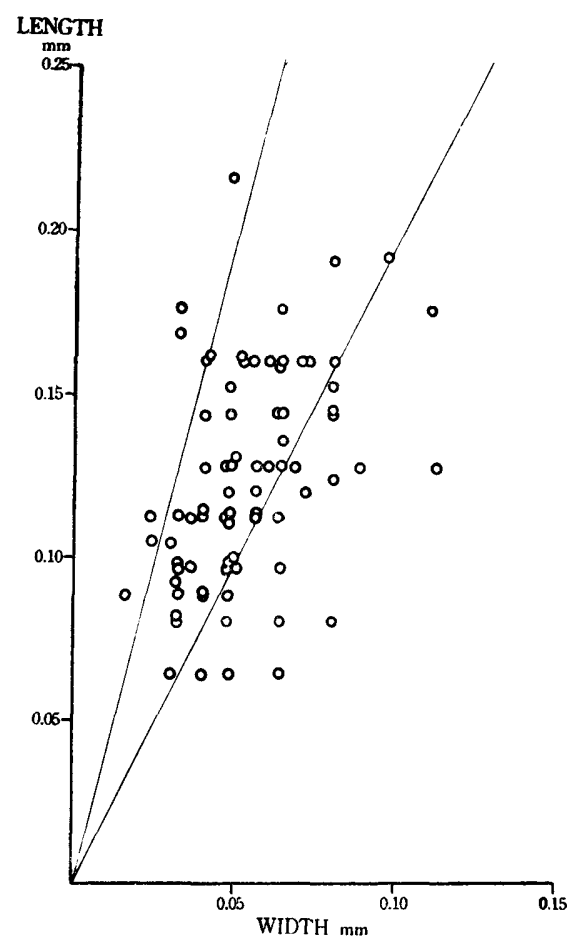

Fig. 14. Elongation diagram of zircon grains. Tuffaceous rocks of the Mifuné group.

tion of the Mifuné group except for tuffaceous rocks in which zircon has somewhat larger elongation ratio than in other rocks (Text-fig. 14).

Many of zircon grains bear inclusions of acicular or pillar-shaped minerals and microlites of zircon itself (Pl. 4, Fig. 1,2), although some of these inclusions are not exactly identified. These inclusions are unoriented in occurrence. Irregular fissures and cavities or vacuoles are frequently observed. Some grains display "worm-eaten" texture.

(3) Garnet.-Three varieties can be recognized; pale purple, amber, and colorless. The pale purple and colorless varieties predominate throughout the Mifuné group.

Garnet grains are for the most part of roughly equidimensional fragments with surfaces of conchoidal fractures (Pl. 4, Figs. 10-13). A vast majority of them is angular or evinces only a slight degree of modification by abrasion, indicating the direct derivation from crystalline source rocks without reworking severely. Some grains show idiomorphs of dodecahedron or rarely of trapezohedron (P1.14, Figs. 1418,20 ), being likely to increase in frequency upwards in the Upper formation. The minority of grains is rounded (Pl. 4, Fig. 19).

Careful examination of individual grains reveals that the grains mostly show some degrees of etching. This gives to the affected grains a hackly apparance (Pl. 
4, Figs. 12, 17, 19, 20): pitting, spotting, and crapy surfaces. Idiomorphic grains are, however, usually of smoothish appearance, although some are blotted and stained (P1. 4, Figs. 14-16, 18).

Inclusions are rather rare, when they do occur, being generally zircon and unidentified others.

More detailed identification of garnet-group mineral is postponed to another study in the future.

(4) Tourmaline.-This is an important constituent, occurring ubiquitously throughout the formation, although its quantity is rather low.

Tourmaline is classified into three varieties primarily on the basis of colors; green, brown, and blue. Pleochroism is very strong and variable: (i) $X=$ colorless to pale brown, $Z=$ blue; (ii) $X=$ colorless to pale brown, $Z=$ deep green ; (iii) $X=$ colorless to yellowish brown, $Z=$ deep brown; (iv) $X=$ pale brown, $Z=$ deep brown; (v) $X=$ reddish brown, $Z=$ deep reddish brown.

The tourmaline grains of green variety are in general of short prismatic crystals, generally terminating with irregular fractures, but occasionally having a pyramidal termination (P1. 5, Figs. 1-3,5). They are rather less rounded. Most of the grains bear inclusions (P1. 5, Fig. 6), being dusted, and coroded cavities are also observed on not a few grains (P1. 5, Fig. 1).

The brown tourmaline is usually granular or irregularly fractured. Prismatic grains are also frequently detected, together with a few grains bounded with pyramidal terminations. This variety of tourmaline is nearly always free from staining and coroded cavities.

The blue variety of tourmaline is scarce in occurrence, but its distribution is characteristic; the upper part of the Upper formation is likely to contain somewhat greater amount of blue tourmaline than other parts. Color and pleochroism are distinct with clearly sky blue along the $Z$-axis. Irregularly fractured grains are common. Few inclusions are perceptible. Milner (1952) and Beveridge et al. (1956) describe the blue tourmaline as indicolite, but the present one under consideration cannot be herein identified precisely.

(5) Chloritic matter.-This is a common constituent, occurring normally as matrix-constituting mineral of irregular flakes or aggregates of fibrous habits. That is C type of occurrence in the definition of SHIRozU et al. (1959), who grouped occurrences of green minerals in three types, A, B, and C. Secondary chloritic matter is also present as a decomposed product of biotite.

Color is variable from dark green to pale green. Pleochroism is very weak but perceptible.

(6) Muscovite.-Muscovite is a ubiquitous mineral of irregular shape, being for the most part fibrous. It is in most cases sericitized. According to Milner (op. cit.), in sediments there are two varieties of muscovite, one floats and the other sinks in 
bromoform. Whether or not may this be due to the different specific gravities of the two varieties, the muscovite flakes have been probably to a certain extent floated away during the separation procedure. Therefore the frequency of its occurrence cannot be precisely estimated.

(7) Biotite.-Two varieties are recognized; brown and green. They are prismatic or of irregular shape, sometimes being bent and fibrous. They are frequently decomposed to chlorite.

(8) Augite.-This is not common, being prismatic, granular and/or irregularly fractured. It is almost colorless or slightly greenish, with very slight pleochroism. Most grains are stained along cavities and fissures.

(9) Common hornblende.-Green common hornblende is usually found as a slender prism (P1. 5, Fig. 9). Pleochroism is distinct; $X=$ pale green, $Z=$ deep green.

(10) Rutile.-This occurs less frequently, but exhibits characteristic distribution, as does purple zircon. Three contrasted types of rutile are met with; (a) well-formed prismatic grains with bipyramidal terminations showing variable degrees of roundness (P1. 5, Fig. 11), (b) anhedral fractured grains (Pl. 5, Fig. 10), and (c) geniculately twinned ones.

Pleochroism is weak but discernible: (i) $\mathrm{E}=$ reddish brown, $\mathrm{O}=$ yellowish brown; (ii) $\mathrm{E}=$ dark yellowish brown, $\mathrm{O}=$ yellowish brown; (iii) $\mathrm{E}=$ amber, $\mathrm{O}=$ greenish yellow.

Cleavages or striations on the grains are observed in two ways: the one which runs obliquely to the prism-edge, the other which exhibits longitudinal striations along the prism.

Radial fissures are occasionally developed, with or without staining and opaque inclusions.

(11) Titanite.-This occurs as a characteristic diamond- or wedge-shaped crystal (P1. 5, Fig. 15). It is almost colorless or yellow to brownish in color. Pleochroism is noted: (i) $\mathrm{X}=$ pale brownish yellow, $Z$ =pale yellow; (ii) $\mathrm{X}=$ nearly colorless, $Z=$ orange. Inclusions and stains are not uncommon.

(12) Anatase.-This is rarely met with as a fairly perfect euhedral crystal, exhibiting bipyramidal habit with striations parallel to the intersection of [111] and [110] (P1. 5, Figs. 12-14). It is weakly pleochroic: $\mathrm{O}=$ yellow, $\mathrm{E}=$ light brown.

(13) Glaucophane.-Only one grain of glaucophane has been detected from the Basal formation (Sp. No. MF. 0011; Pl. 5, Fig. 8). It is undoubtedly diagnosed with its characteristic pleochroism: $Z=$ blue, $Y=$ lavender or violet. In such a marked pleochroism, however, the present mineral is very similar to riebeckite, but the mineral now in question is clearly distinguished from the latter in stronger birefringence and positive elongation, although other optical properties cannot be obtained.

(14) Apatite. - This is noticeably present only in tuffaceous rocks such as tuff and tuffaceous sandstone (see p. 21). It has ordinarily a slender prismatic habit and 
is sometimes stoutly prismatic (P1. 5, Figs. 16-19). It attains $0.14 \mathrm{~mm}$ in length in the largest crystal. Most of apatite crystals occur in a fresh appearance. Occasionally indeterminable species of microlites are included longitudinally and/or at random. More or less rounded outline of the apatite grains seems, in most cases, to be due to $\mathrm{HCl}$ in the course of heavy mineral separation. No "cored apatite" is met with.

(15) Short summary.--Summarizing the above descriptions, the Mifuné group is as a whole characterized by the preponderance of the epidote group.

The Basal formation is clearly distinguishable from the overlying formations in the common occurrence of rutile and well rounded purple zircon together with the presence of glaucophane and anatase. In particular the former two are significant as index minerals. The relation between the Lower and Upper formations is rather gradational in heavy mineral composition, although in the Upper formation rutile reappears sporadically and blue tourmaline and euhedral garnet of dodecahedron or trapezohedron are more frequently met with.

The horizontal variations of the heavy mineral frequencies are perceptible, as is reviewed in p. 27 .

\section{Notes on tuffite and tuffaceous sandstone}

\section{a. Tuffite}

(1) Occurrence.- In the Mifuné group a thin bed of a flinty tuffite is intercalated at about twelve horizons. It occurs more frequently in the Upper formation. It is useful as a key bed in field mapping (Text-fig. 1). The occurrence of tuffite and also of tuffaceous sandstone is significant in that it indicates volcanic activities in the period of sedimentation.

Tuffite is megascopically bluish green to light bluish gray, compact, and hard in a fresh specimen, presenting a flinty appearance. Very rarely red-tinted tuffite is met with (e.g. loc. MF. Ex. 60').

On the exposures the tuffite is as a rule weathered to white along well-developed prismatic jointings whereby it tends to divide easily into columnar fragments.

(2) Texture and mineral constituents.-Major constituents of tuffite are extremely fine-grained matrix, microlites, and grains of detrital and volcanic origins. There remains a vitroclastic texture in the matrix ( $\mathrm{Pl}$. 3, Figs. 2,3), despite its more or less altered condition. Laminations are rarely developed microscopically from the arrangement of vitric shards.

Thus four major textural varieties are distinguishable in tuffite: the first is only composed of extremely fine-grained matrix and microlites; the second is that in which glass fragments are added at random to the above; the third is of a laminated texture; the fourth is of a porphyritic texture scattered with irregular grains of variable sizes. 
Table 5. Mineral compositions of some selected tuffaceous rocks of the Mifune group

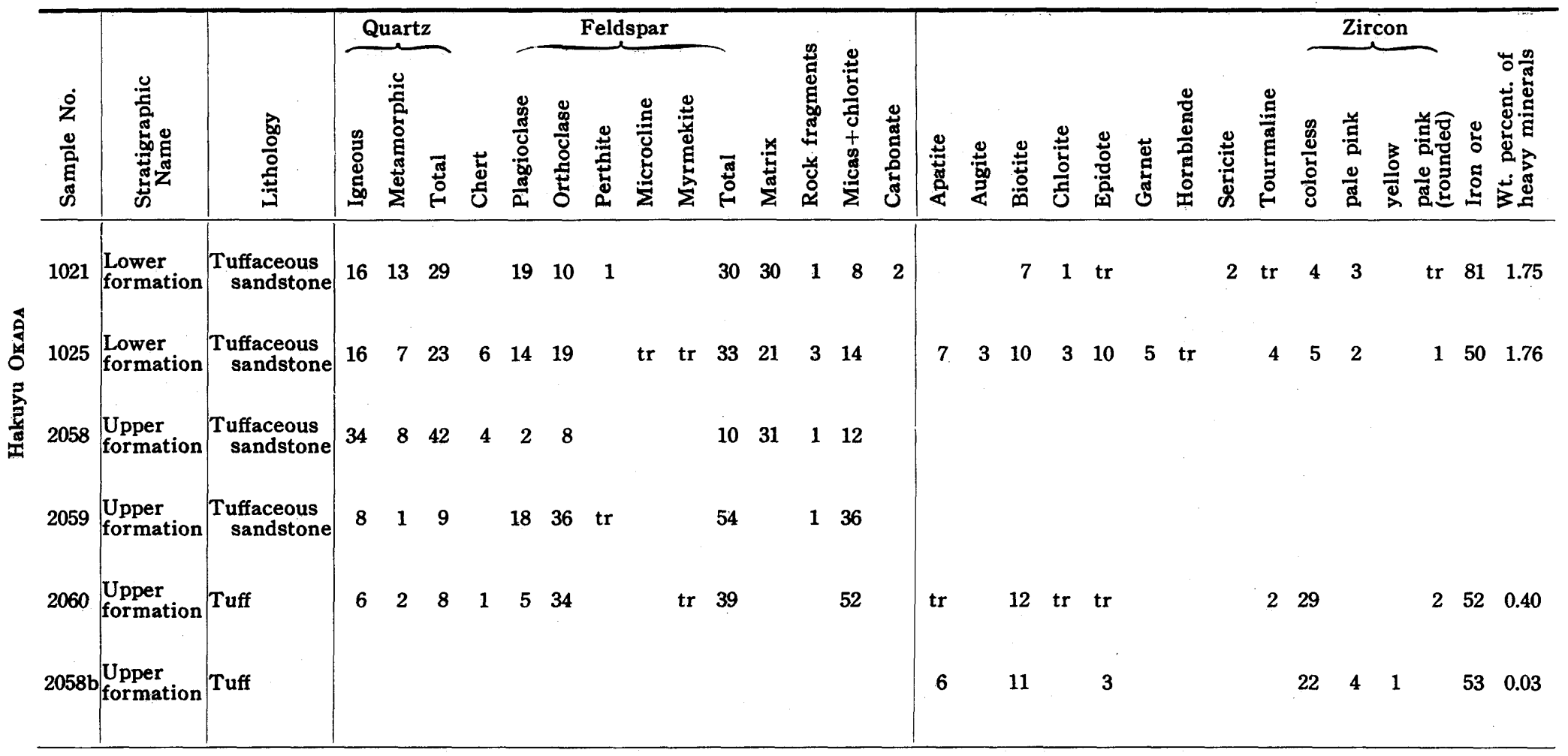


(3) Matrix.-The matrix is mainly composed of glass, chloritic matter, silica, calcite, iron minerals, and so forth. The matrix is more or less altered mainly by silicification, which leads to a flinty rock, and partly by carbonitization.

(4) Microlites. - Microlites $(0.1-0.001 \mathrm{~mm}, 0.05 \mathrm{~mm}$ on the average) are subhedral and angular, consisting of plagioclase (andesine-labradorite) and less amount of quartz and orthoclase.

(5) Vitric fragments. - In many cases there remains vitroclastic texture which shows a peculiar structure and characteristic form of volcanic glass in way of shards, cusps, vesicles, and the like, as illustrated by Pirsson (1915). Some parts of the glass fragments are devitrified and in part altered to chalcedony and the like. One specimen [Sp. No. MF. Ex. 60'] exceptionally shows that almost all of the glass particles were subjected to devitrification which was entirely followed by silicification.

(6) Calcite.-Some parts of the tuffite are indurated by calcite. It fills the interspaces of microlites and matrices, and occasionally replaces some of them.

(7) Plagioclase.-Plagioclase is represented by andesine to labradorite. It attains about $0.05 \mathrm{~mm}$ in the maximum length on the average, occurring as subhedron to anhedron. Albite twinning is common, and Carlsbad and Carlsbad-albite twinnings are also met with.

(8) Chloritic minerals. - These may be the alteration products of ferromagnesian minerals, constituting a part of the matrix.

(9) Quartz.-Quartz, $0.08 \mathrm{~mm}$ on the average, is anhedral, making up microlites. Almost all of the quartz fragments are igneous quartz, but metamorphic quartz is also very rarely detected.

(10) Orthoclase.-Orthoclase, less in amount, is anhedral and slightly rounded. Carlsbad twinning is common.

(11) Micas. - Biotite, 0.03 to $0.7 \mathrm{~mm}$ in length, is frequently met with. It occurs as long shreds; some of the biotite flakes are bent and broken. Many flakes show various degrees of alteration. Muscovite and sericite are also present in small amount.

(12) Heavy minerals.-By far the most abundant among heavy minerals are iron ore minerals. Next to them, zircon and biotite are rather abundant. Others, such as tourmaline, epidote, apatite, and chlorite, are common. The heavy mineral associations are shown in Table 5. Some of these minerals might have been mingled into tuffite from preexisting acid igneous rocks and schists, together with some of quartz and feldspar grains.

\section{b. Tuffaceous sandstone}

(1) Occurrence.-Both in the Lower and Upper formations are intercalated a few beds of tuffaceous sandstone, 3 meters or less thick. It is more or less silicified, presenting similar features to the tuffite.

(2) Texture and mineral constituents.-The greater portion of the rock, exceed- 
ing 60 percent, consists mainly of detrital grains of quartz, feldspar, rock fragments, and so forth, as shown in thin sections. The rock contains, on the average, 32 percent feldspar. Next in order of abundance is the tuffaceous matrix, which is to a good extent chalcedonized. The remainder of the rock consists of various types of quartz, rock fragments, and chert (Table 5). Relicts of volcanic glass are sometimes clearly traced in the matrix (Pl. 3, Figs. 5,6), presenting a vitric texture.

(3) Plagioclase--Plagioclase ranges from labradorite to andesine and partly shows a certain degree of alteration to kaolin and a micaceous type of clay mineral. Plagioclase grains are subhedral to euhedral. Albite twinning is common, while Carlsbad and Carlsbad-albite twinnings are also present. Zonings are commonly observed.

(4) Orthoclase.-Orthoclase displays weak but rather extensive kaolinitization and other alterations. Carlsbad twinning is common. It is slightly rounded, suggesting an effect of transportation.

(5) Quartz.-There are two varieties of quartz, of which the igneous quartz greatly exceeds in amount the metamorphic. Among the grains of the igneous quartz are commonly recognized those of an elongated tabular-type quart $z$ which suggests evidently the volcanic origin (WEAVER, 1955). The rest grains of the igneous quartz are better rounded, being probably of detrital origin.

As an authigenic matter, chalcedonic and microcrystalline silica minerals are present, constituting interlocking masses between larger detrital grains. These authigenic minerals seem to grade into one another. In some parts they occur as tightly packed grains of quartz less than some 70 microns in diameter, exhibiting irregular-interpenetrating boundaries, and each grain displays more or less undulating extinction. While in other parts chalcedonic silica is made up of radiating fibers, the indices of refraction being lower than that of the norwal quartz.

(6) Calcite and chloritic minerals.-Calcite occasionally fills the interspaces of the matrix. Chloritic minerals may be of the alteration product of ferromagnesian minerals. They are present as constituents in the matrix, being more or less ovoid in shape.

(7) Rock fragments.-Rock fragments are present in most of the tuffaceous sandstone, normally 1 percent of the rock but in one case rising 3 percent. Almost all of the rock fragments are of acid igneous rocks, presenting a hyalopilitic texture. It is not evident, however, whether they are related to volcanic ejecta, because they are not dissimilar to those in other sandstones.

(8) Heavy minerals.--Apart from the iron ore minerals, the most abundant heavy minerals are zircon and biotite (Table 5). There seems to be little variation in these minerals. Others are tourmaline, epidote, apatite, chlorite, garnet, and pyroxene, all of them being variable in amounts. The heavy mineral composition of tuffaceous sandstone is not basically different from that of tuffite (see also Table 5). 


\section{c. A short summary of tuffaceous rocks}

The tuffite is markedly characterized by a vitric texture due to glass fragments constituting a greater portion of the rock. As a conclusion, nature of plagioclase feldspar and a quantity of quartz suggest that the present rock is a quartz-andesitic or dacitic tuffite, which has subsequently suffered from silicification and less degree of carbonitization.

In the meanwhile, the tuffaceous sandstone has a matrix where in parts is clearly traced a vitric texture. At the same time it bears probable volcanic ejecta as well as somewhat more abundance of detrital grains, as are mainly observed in quartz and feldspar. As to the origin of the tuffaceous sandstone, it is much related to the tuffite mentioned above.

These tuffaceous rocks are distinctively characterized by the presence of an accessary mineral of apatite.

\section{Note on red beds}

The red beds of the Mifuné group, constituting 35 to 40 percent of the whole group (Mатsumoto [Editor], 1954, p. 198, Fig. 43), are almost restricted to siltstones or mudstones. Exceptionally very small parts of sandstones and basal conglomerates are red-tinted. The color of the average red siltstone is dusky red to moderate red (5 R 3.5/4), according to the rock color chart (GoDDARD [Chairman], 1951). The red siltstone is rather massive and shows conchoidal fracture. It is graded into concomitant greenish shale which is as a rule accompanied by grayish green sandstone (color: grayish green, $10 \mathrm{GY5} / 2$ ). Sometimes calcareous concretions occur in the red shale but no fossil remains have been found as yet.

Mechanical analysis and the composition of the grains are difficult to measure and determine because of their small size and extremely thick coating of clay. The D.T.A. data of red siltstone reveal illite-like curves, as is illustrated in Text-fig. 15. Van Houten (1948) reports illite as the predominant clay mineral in various western red beds in the United States and also SwinEFord (1955) stresses that illite rather than kaolinite is the predominant clay mineral in the Upper Permian Kanas red beds. On the contrary, kaolinite and gibbsite are predominant in the Triassic Newark red beds of Connecticut by KRYNINE (1950). This is merely because of the environmental difference between the terrestrial and saline-basin deposits (SwINERORD, op. cit.). To make a comment on the Mifuné red beds from such a point of view, further detailed mineralogical study of clay is needed.

In addition, chemical analysis data of a selected specimen of red siltstone (Sp. No. MF. 2056) show that $\mathrm{Fe}_{2} \mathrm{O}_{3}$ content is 15.67 percent. CLARKE's (1924) average shale contains 4.02 percent of $\mathrm{Fe}_{2} \mathrm{O}_{3}$, which is much lower than the iron oxide content of 15.67 percent in the Mifuné red siltstone. This value of $\mathrm{Fe}_{2} \mathrm{O}_{3}$ content of the Mifuné red siltstone is considerably high. In contrast with that, SwINEFord (op. cit.) points 

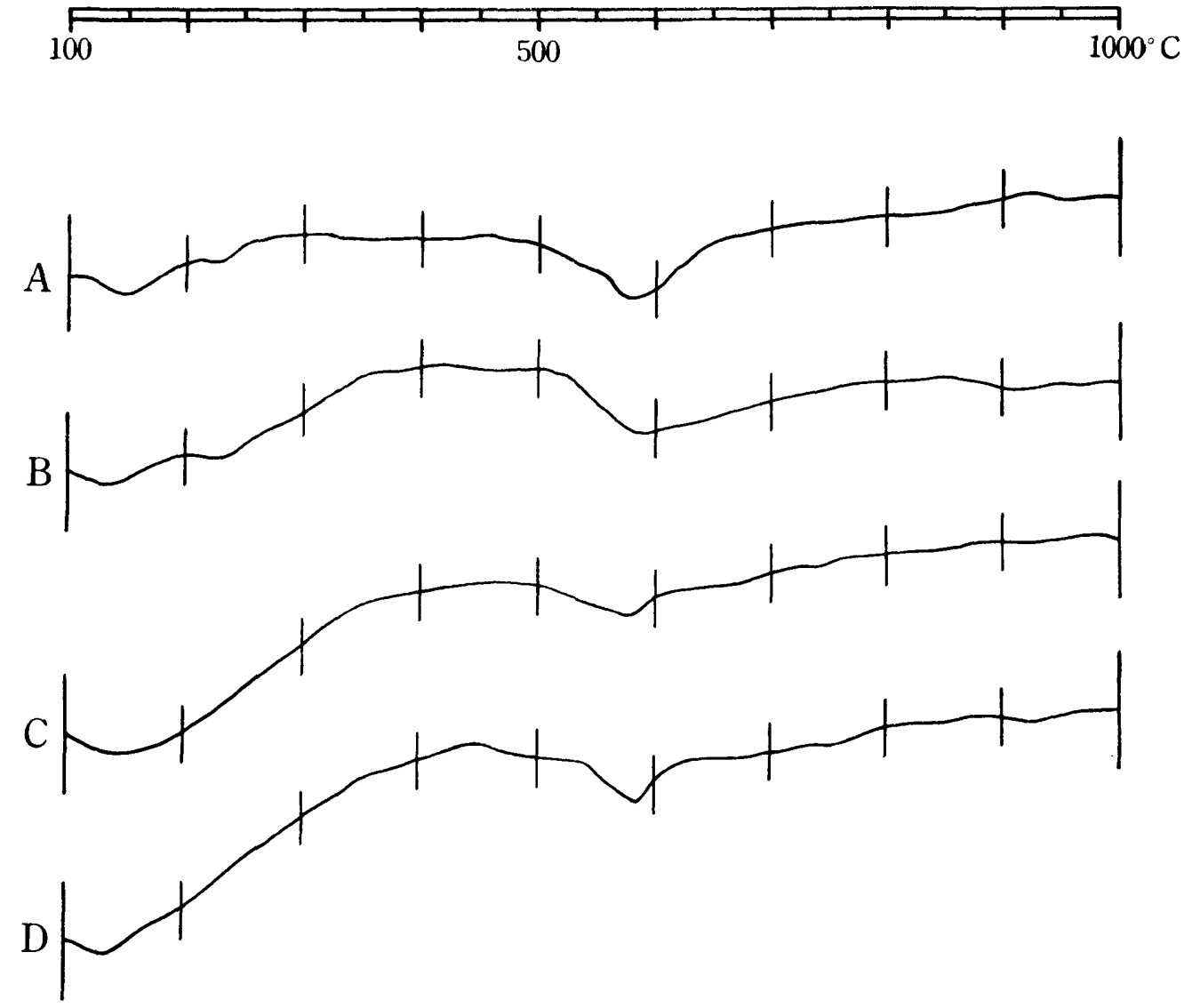

Fig. 15. Data of differential thermal analysis of selected samples of reddish sediments.
A : very fine-grained sandstone; Sp. No. MF. Ex. 1
B : siltstone; Sp. No. MF. 2111
C: fine-grained sandstone; Sp. No. MF. Ex. 2
D: medium-grained sandstone; Sp. No. MF. Ex. 3

out that an unexpected character of the Permian Kansas sediments is their low percentage of $\mathrm{Fe}_{2} \mathrm{O}_{3}$ (0.79 to 5.87 percent), despite their common bright-red coloration, further commenting that the lower values for $\mathrm{Fe}_{2} \mathrm{O}_{3}$ in the Permian shale seemingly cannot be attributed to dilution with free $\mathrm{SiO}_{2}$.

Mica consists chiefly of small shreds of sericite-like mineral and might be a part of the matrix.

The red-tinted sandstones are insignificant in amount, as mentioned above. Almost all the grains are coated with red clay; some grains are perticularly heavily coated with red iron oxide (Pl. 3, Fig. 1). No chemical cement such as calcite and silica is observed. The results of the thin-section observations and heavy mineral analysis are included in Tables 2 and 3. Although the heavy mineral composition of the reddish sandstones is not basically different from the non-reddish ones, hematitic 
iron spaques constitute the greatest proportion of heavy minerals. X-ray diffraction data of such an iron mineral indicate hydrated hematite (Table 6).

Table 6. X-ray data of hematite* from the sandstones of the Upper formation

\begin{tabular}{c|c|c||c|c|c||c|c|c}
\hline $\mathrm{d}(\AA)$ & $\mathrm{I}$ & & $\mathrm{d}(\AA)$ & $\mathrm{I}$ & & $\mathrm{d}(\AA)$ & $\mathrm{I}$ & \\
\hline 7.72 & $\mathrm{I} / 2$ & & 2.28 & 2 & $\mathrm{Q}$ & 1.481 & 4 & $\mathrm{H}$ \\
4.40 & 4 & $\mathrm{Q}$ & 2.22 & 2 & $\mathrm{H}+\mathrm{Q}$ & 1.450 & 5 & $\mathrm{H}$ \\
4.03 & 2 & $\mathrm{Cr} ?$ & 2.13 & 3 & $\mathrm{Q}$ & 1.371 & 7 & $\mathrm{Q}$ \\
3.35 & 10 & $\mathrm{Q}$ & 1.997 & 1 & $\mathrm{Q}$ & 1.346 & 1 & \\
3.20 & 4 & $\mathrm{Ca}$ & 1.885 & $\mathrm{I} / 2$ & & 1.313 & 1 & $\mathrm{H}$ \\
2.96 & $\mathrm{x} / 2$ & & 1.822 & $5 \mathrm{~L} / 2$ & $\mathrm{H}$ & 1.283 & 1 & $\mathrm{Q}$ \\
2.71 & 5 & $\mathrm{H}$ & 1.683 & $5 \mathrm{~T} / 2$ & $\mathrm{H}$ & 1.253 & $3 \mathrm{x} / 2$ & $\mathrm{Q}$ \\
2.53 & 5 & $\mathrm{H}$ & 1.663 & $\mathrm{x} / 2$ & $\mathrm{Q}$ & 1.225 & 1 & $\mathrm{Q}$ \\
2.45 & 3 & $\mathrm{Q}$ & 1.594 & 1 & $\mathrm{H}$ & 1.195 & $3 \mathrm{~K} / 2$ & $\mathrm{Q}$ \\
2.40 & 1 & & 1.532 & $4 \mathrm{~L} / 2$ & $\mathrm{Q}$ & 1.177 & $3 \mathrm{x} / 2$ & $\mathrm{Q}$ \\
\hline
\end{tabular}

Note: Camera radius $28.65 \mathrm{~mm}$. $\mathrm{FeK}_{a}$ radiation.

Q: Quartz $\mathrm{Cr}$ : Cristobalite Ca: Calcite $\mathrm{H}$ : Hematite

\section{Petrological Remarks}

\section{Summary of quantitative aspects}

Before giving some comments on source rocks of the detrital deposits of the Mifuné group and a relation between tectonics and sedimentation during its deposition, it is better to figure out and summarize herein quantitative aspects of some factors analysed in the preceding chapter (see Text-fig. 16).

Almost all the sandstones sampled are graywacke in character, and the most abundant constituent is quartz. The relative abundance of the varieties of quartz show some minor horizontal variation within the basin of the Mifuné group. Thus the metamorphic variety is somewhat more abundant in the northeastern part of the basin than in the southwestern, although the difference become rather obscure in the Upper formation of the Mifuné group. On the contrary, the roundness of quartz grains is slightly better in the southwestern part than in the northeastern.

Feldspar is not abundant in these graywacke sandstones except in tuffaceous sediments. Among several varieties recognized, plagioclase and orthoclase show a higher frequency in occurrence. No significant horizontal and vertical variations have been recognized as regards kinds and amount of feldspar.

Of other major constituents of sandstones, clay matrix constitutes as much as about 40 to 50 percent of the rock, while rock fragments are present in small amount. Again no regularity is noted concerning the horizontal and vertical distributions of matrix and rock fragments.

* Separated from the specimens of MF. 2012 and 2093. 


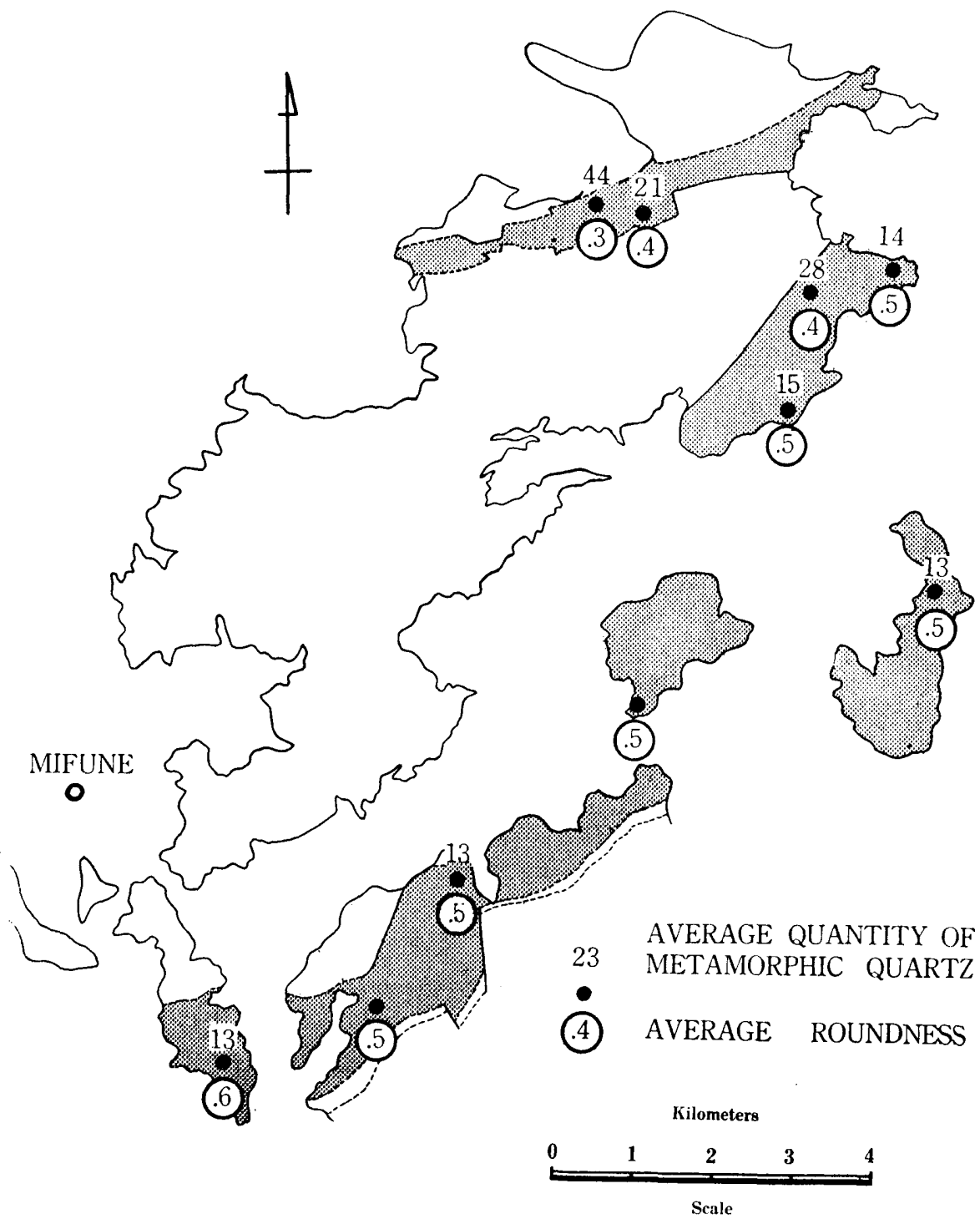

Fig. 16. Horizontal variations in roundness of the quartz grains and quantity of the metamorphic quartz at the stage of the Lower formation.

Regarding the non-opaque heavy minerals, the general order of abundance is: epidote $>$ zircon $\gg$ garnet $>$ tourmaline $\gg$ augite $>$ hornblende $\gg$ rutile $>$ anatase $>$ titanite $>$ glaucophane. Four varieties of zircon are recognizable. Purple zircon is the most significant; it is stratigraphically characteristic of the Basal formation and horizontally highly concentrated in the southern part of the basin. The roundness of zircon is evidently higher in the Basal formation than in the overlying formations in that it is proportional to the amount of the purple zircon (Text-fig. 9). In addition, the elongation ratio (length/width) of zircon in the Basal formation presents 1 to 2 ratio 
of elongation on the average, whereas that in the Lower and Upper formations falls in 1.5 to 2.5 (Text-figs. 11-13). Zircon of tuffaceous rocks shows higher elongation ratio on the average than the above (Text-fig. 14)

Rutile also seems to be concentrated in the Basal formation.

Another aspect is that biotite flakes occur more abundantly in the northeastern part than in the southwestern part. This is especially evident when the Lower formation is considered.

\section{Source rocks}

\section{a. Heavy mineral suites}

Heavy minerals are considered to be one of the most effective clues to deduce mother rocks of detrital grains. From this point of view some definite assemblages of heavy minerals are given for their probable source rocks (KRUMBEIN et al., 1938; Pettijohn, 1957; Fujir, 1958; IIjima, 1959b). Although heavy mineral assemblages may vary in detail even in one and the same formation, a given formation has as a rule sandstones characterized by definite suites of heavy minerals distinguishable from those of other formations. Apart from heavy mineral suites, a particular mineral characteristic of a certain formation is appropriately called the "index mineral" just in a similar way to Fujri's (1958, p. 139).

The three formations of the Mifuné group have the following heavy mineral suites and index minerals.

(1) Basal formation.-The heavy mineral assemblages of the Basal formation are composed of the following five suites:

(a) : Epidote-garnet-glaucophane-tourmaline (brown)

(b) : Zircon-tourmaline (green)-rutile-garnet-biotite-muscovite

(c) : Zircon-anatase

(d) : Augite-hornblende

(e) : Rounded zircon-rounded rutile

They are probably originated from metamorphics (mainly green schists), acid plutonics, porphyritic rocks, andesitic rocks, and older sediments, respectively. No regularity can be recognized in distributions of each of the above.

The index minerals are purple zircon and rutile, the high contents of which discriminate the Basal formation definitely from the overlying two formations of the Mifuné group.

(2) Lower formation.-The heavy mineral compositions of the Lower formation are somewhat different from the underlying Basal formation. The assemblages of its heavy minerals consist of the following four suites:
(a) : Epidote-garnet-tourmaline (brown)
(b) : Zircon-tourmaline (green)-garnet-biotite-muscovite-hornblende
(c) : Hornblende-augite 
(d) : Rounded zircon

They are brought from metamorphics (green schists), acid plutonics, andesitic rocks, and older sedimentary rocks, respectively. The index mineral is epidote.

(3) Upper formation.-The associations of heavy minerals of the Upper formation are basically unchanged from those of the Lower formation. The following five suites are recognized:

(a) : Epidote-garnet-tourmaline (brown)

(b) : Zircon-garnet-tourmaline (green)-biotite-muscovite-hornblende-rutile

(c) : Augite-hornblende

(d) : Blue tourmaline

(e) : Rounded zircon

The deducible source rocks are, thus, metamorphics, acid plutonics, andesitic rocks, pegmatitic rocks, and older sediments, respectively. The index mineral is also epidote.

From the suites of heavy minerals remarked above, materials of a given sandstone are inferred to have originated from metamorphics (possibly green schists), acid plutonics, porphyritic rocks, andesitic rocks, pegmatitic rocks, and older sediments. This is warrantably supported by major constituents of the sandstone and pebbles of conglomerate.

For better understanding of the provenances, it is appropriate to refer to some selected heavy minerals.

\section{b. Problem of zircon}

A special comment is to be given on well-rounded zircon which is characteristic in distribution. The rounded grains of zircon, including a purple variety, are very remarkably abundant in the Basal formation, especially on the southern wing of the formation where the Upper Permian Mizukoshi formation unconformably underlies it. The prevalence of rounded zircon suggests that the grains have suffered from serious abrasions for many times, since the smaller euhedral crystal is apt to remain unaltered as it was even after a long transportation (PoldervaART, 1955). Most of such zircon grains may have been multicycled.

In addition, YANAGIDA (1958) reported that the Mizukoshi formation bears several thick beds of conglomerate consisting mainly of boulders to pebbles of granitic rocks which contain purple to rose pink zircon. Furthermore, I have ascertained the presence of purple zircon in the available sandstone samples from the same formation (Table 7).

Tоміт (1954), commenting on the mass color of granitic zircon, says that variation of its color depends upon the age of formation of granite from which zircon was derived, and has emphasized that purple zircon stands for the Pre-Cambrian 
Table 7. Mineral compositions of some selected sandstones of the Upper Permian Mizukoshi formation

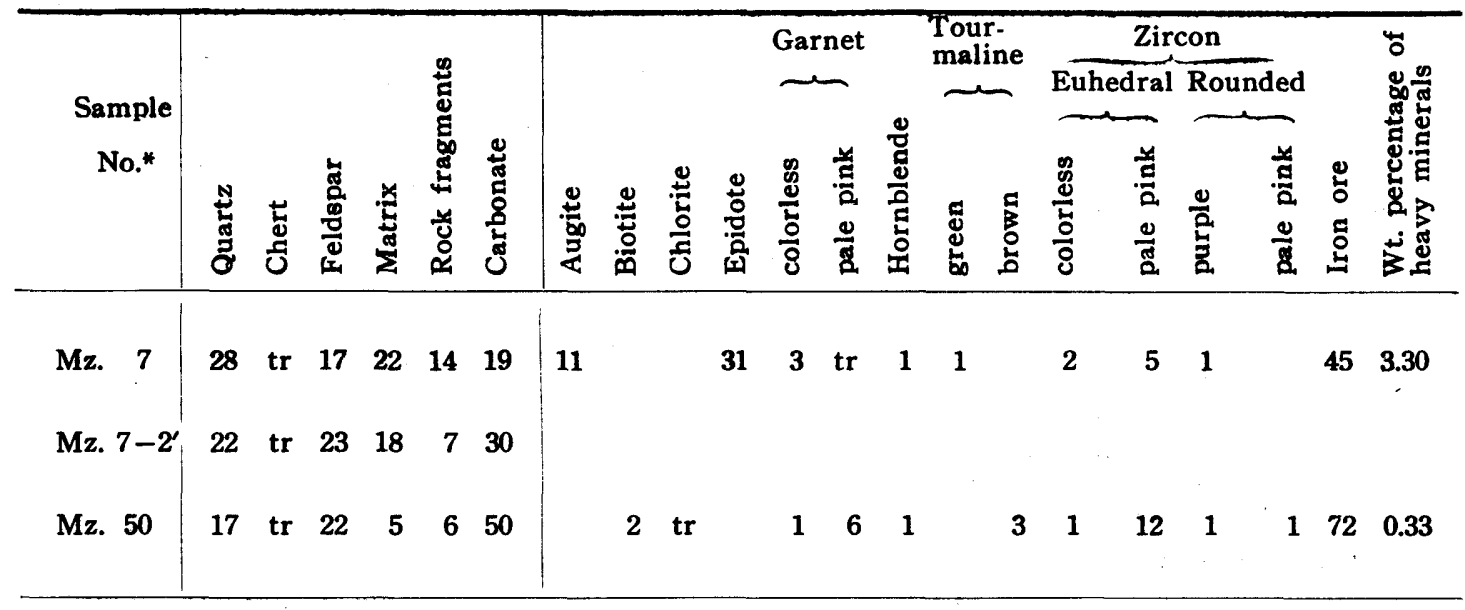

but never for other ages. According to his law of experience, the ultimate origin of the well rounded purple zircon of the Mifuné group should be in the Pre-Cambrian granites.

The mass color of zircon** in a granitic cobble (granite-porphyry) of the Basal formation of the Mifuné group is verifiably correlated to that of the Asakura-type granite (KARAKIDA, 1952), to which that of granitic gravels from the Ryozen formation of the Lower Onogawa group, approximately contemporaneous with the Mifuné group, is also correlated (Tomis et al., 1957). This fact leads us to conclude that, so far as the available data are concerned, some of the constituents of the Mifune group may have shared their provenances with those of the Lower Onogawa group, among which porphyritic and granitic rocks may be predominant.

To make a speculation on the provenance of the detrital gravels of the Asakuratype granite, the Tamana granodiorite (YамAмото, 1955; Fujimoto et al,, 1960) is most warrantably referred to, which is distributed 30 to 35 kilometers northwest of the Mifuné area and is reported to accompany hornblende-biotite-porphyrite (FuJIMOTo et al., 1960, p. 32), supporting the association of the porphyritic rocks as pebbles of conglomerate in the Mifuné group.

Concerning the elongation of zircon, MAтsumoto et al. (1953) reported that high elongation ratio of zircon is typical of some volcanic rock. Tuffite and tuffaceous sandstone of the Mifuné group also contain zircon with higher elongation ratio (Text-fig. 14). Thus such an elongated type of zircon in the sandstones of the Mifuné group might be from volcanic rocks, although the case cannot be ruled out easily, as commented by PoldervaArT and other (Polde rvaART, 1956, pp. 548-550; Yamaмото, 1959).

* Yanagida's sample number.

** Mr. Yoshifumi Karakida kindly helped me in identifying the mass color of zircon. 


\section{c. Problem of epidote}

Epidote is of so significant mineral as to be regarded as an index mineral of the Mifuné group. Its crystal habits and its occurrence lead us to believe that this mineral is of detrital origin. Although the provenance of epidote cannot be simply interpreted, I am inclined to consider that the origin of epidote in the Mifune group may be in metamorphic rocks, especially crystalline schists, together with garnet and zoisite, in a similar way to Petrijohn's (1957). In the meantime, FujII (1956), commenting on epidote and zoisite in the Mesozoic sandstones in the Yatsushiro district, says that their abundance is directly proportional to that of igneous rock fragments, and casts a question that epidote and zoisite, together with garnet, are not always of metamorphic origin.

According to certain previous works (FuJII, 1956, 1958; IIJIMA, 1959a, 1959b) and my own preliminary examinations, Cretaceous sandstones in Japan are characterized by the preponderance of epidote-group minerals. Thus the origin of epidote group minerals in each of depositional basins should be clarified in association with respective possible provenance, together with their detailed mineralogical study.

\section{d. Problem of glaucophane}

From a sandstone specimen of the Basal formation (Sp. No. MF. 0011) was detected only one individual grain of glaucophane, to which that mineral grain is verifiably identified (see p. 20). This is as much significant in that glaucophane is a product of particularly restricted condition of metamorphism (MrYASHro et al., 1958; MIYASHIRO, 1958).

According to MiYashiro and other (MIYAShIro, op. cit.; SeKI, 1958), glaucophanatic metamorphism is characteristic of the Sambagawa metamorphic belt. On the other hand, glaucophane is met with in the "Kiyama crystalline schists", a basement of the Mifuné group (observation of myself and oral communication of YAMAOKA*), which are with contraversies regarded as a possible western tip of the Sambagawa metamorphic belt proper. At the same time, the "Kiyama crystalline schists" bear piedmontite (oral communication of YAMAOKA), as characteristically does the Sambagawa metamorphic belt (MrYASHIRO, op. cit.), but I have not yet detected it in the sediments of the Mifuné group proper. Thus, however, the "Sambagawa type metamorphic rocks" in the "Kiyama crystalline schists" may have been one of the important contributors of detritus to the Mifuné group.

\section{e. Problems of tourmaline, anatase, and apatite}

Tourmaline is a mineral which is commonly met with in the sandstones of the Mifuné group. Several varieties of tourmaline are recognizable mainly by its colors (p. 19).

* Ex-Assistant Professor of the Kumamoto University; now at the Tohoku University. 
KRYNINE (1946) treated inclusions as well as pleochroism in detail and classified tourmaline into 13 subspecies, correlating them to five expected provenances. According to him, blue variety is a pegmatitic tourmaline, pale to deep brown variety is a tourmaline from pegmatized injected metamorphic terranes, and green variety is a granitic tourmaline.

Thus, if studied systematically and in detail, tourmaline may present an effective clue to infer the provenance.

On the other hand, anatase occurs as an unabraded crystal which seems to reveal that it was produced in situ as a secondary mineral probably due to the decomposition of titaniferous minerals such as ilmenite and the like.

FUJII (1956) says in his study of the Mezosoic sandstones of the Yatsushiro district that anatase is as a rule found in the basal coarse-grained sandstones together with probably authigenic pyrite. Thus he concludes that they might be significant as minerals indicating a particular environment of sedimentation. In this respect it is interesting that anatase in the Mifuné group is also traced only in the basal part of that group (Sp. No. MF 0010; 0011).

Apatite is exclusively recognized in the tuffaceous rocks, so it many have been brought into tuff and tuffaceous sandstone as a material of volcanic origin but not of detrital one.

\section{Sedimentation condition and tectonics}

At the time of deposition of the Basal formation, the subsidence was very intense on the northern wing of the basin probably under the control of basinmaking tectonic movements. At the same time, a landmass presumably to the north of the basin was rapidly rising from which were contributed the bulk of detritus to form terrestrial fanglomerate. Low roundness and poor sorting of the pebbles of conglomerate reinforce the conclusion that they were not transported for a great distance.

In the meanwhile, on the southern wing the subsidence was less intense, and the contribution of detribtus was also in less amounts. From place to place in the conglomerate an imbricated structure is recognized, presenting a current action.

As a whole it is concluded that the intercalation of red beds in the Basal formation suggests deposition in the subaerial environments.

Following that period, rising of the source areas got less intense to have resulted in deposition of finer clastics of the Lower formation. At this time of deposition, subsiding center of the basin was shifted to the southern part and the basin got a connection with the sea-water through the southwestern path.

The following is some conspicuous features of the Lower formation:

Northern wing. 1) Molluscan fossils of brackish water are abundant. 2) Sandstone is prevalent in the lower part, exhibiting a cross-bedded structure. 3) In the 
upper part black shale is overwhelmingly predominant and somewhat calcareous, with intercalation of a limestone lense; thin beds of coaly shale are sometimes accompanied; sandpipes are also met with. 4) Mica flakes are concentrated.

Southern wing. 1) The Lower formation is represented by predominant sandstones which are rather massive and scarecely show graded-bedding. 2) Fossil remains are common, some of which such as trigonids and inocerami point to opensea environment.

Thus. succeeding the deposition of the Basal formation in a closed basin, a detritus supplied from surrounding uplands settled partly in deltaic and lagoonal conditions, rarely subaerially, continuing sedimentation for the most part in brackish or shallow-sea water in the northern part. And prior to the deposition of the terrestrial Upper formation, the basin was generally under a calm condition favorable for deposition of micaceous shale with local limestone or calcareous sediments.

On the other hand, on the southern wing the sedimentation condition was somewhat different from that of the northern wing in that this part of the basin was affected by sea-water with current activity, although at the lower stage of deposition of the Lower formation the basin even in this part seems to have been controled by a regressive condition as is understood by the presence of coal and plant materials.

At the end of sedimentation of the Lower formation terrestrial or subaerial condition began to control the basin as in the stage of the Basal formation. It is noteworthy that the Upper formation which attains the thickness as large as about 700 meters does not present any distinguishable variances in lithofacies vertically as well as horizontally. The fact supports to conclude that the sedimentation condition in this period continued throughout without any marked changes, and indicates relative tectonic stability of the area. The Mifuné red beds are confined almost to siltstone or shale except for some parts of sandstone and tuffite. A selected sample of red siltstones contain as much as 15.67 percent $\mathrm{Fe}_{2} \mathrm{O}_{3}$, as is estimated in chemical analysis. In addition, an examination of hematitic iron mineral from red-tinted sandstones reveals hydrohematite, a variety of normal hematite. Thus the mineral of hematite is responsible for the red coloration in all the red beds now in question. For the formation of hematite an intense oxidizing environment with high Eh values and high temperature is needed (KRUMBEIN et al., 1952), because red pigmentation is characteristic of the soils of low latitudes.

For reference to the problem of red beds the nearly contemporaneous "Kenseki series" is compared with the Mifuné group. The bulk of volcanic materials contained in the "Kenseki" have been hitherto considered to have played a distinctive role in red coloration. However, as has been emphasized by KoBAYASHI (1954), UYEDA (1957), HASE (1958), etc., I am also inclined to believe that climatic condition was more seriously important for red coloration as in the Mifuné group, principally because 
volcanic materials are also equally met with both in red sediments and in non-red ones from the Sasayama series* (equivalent of the "Kenseki series) (Onoyama, 1931; Matsushita, 1953; Kusumi, 1958) of Hyogo Prefecture as well as from the "Kenseki series" of the type Kwanmon area (UYEDA, op. cit.).

The origin of the bulk of red beds is hard to be precisely concluded here at the present state of knowledge. However, it may be said that the Mifuné red beds are not considered to have been produced chemically by precipitation from solution, because of no accompanyment of layers of rather pure iron oxide, as SwINEFord (op. cit.) postulated in her study of the Kansas red beds. But, from the occurrence of red beds of the Mifuné group which are restricted almost to siltstones or shales but not to sandstones, it might be suggested that the Cretaceous red beds of Mifuné were produced from red soils, and their pigment was developed by weathering of iron-bearing minerals at the source-areas, and incorporated into the resulting sediments after erosion and transport; this is the primary red beds, according to a fourfold classification of red beds presented by KRYNINE (1949).

Greenish graywacke type sandstones of moderate thickness occurring concomitantly in the red sediments of the Upper Mifuné exhibit in general finely laminated texture (Pl. 1, Fig. 4), but no remarkable graded bedding. These greenish sediments yield abundantly plant remains of Platanus sp. and other plant fragments, although their localities are restricted. And also some beds of coal and/or coaly shale are sometimes intercalated.

Such a greenish appearance seems to be to a great extent attributed to chloritic matters (see p. 12, Text-fig. 7), while accessary mineral of epidote might be also to a certain extent related to this respect.

In addition, the presence of tuffite at several horizons of the Mifune group is of great significance in that it reveals volcanic activity during the period of sedimentation. Although Suzuki (1932) pointed out that the Mesozoic tuff in Japan has a certain tendency in nature depending on its age, there are many other different cases at the present state of knowledge**. In this connection, to discuss geological significance of the tuffite of the Mifuné group, further comparative study with other regions is needed.

All things considered, the moderate thickness and areal extension of the present Cretaceous rocks indicate somewhat geosynclinal character, as MAтsumoto (1953) has depicted a picture of brachygeosyncline.

The sandstone studied are graywacke in nature, being immature with higher proportion of muddy matrix. This is reasonably harmonious with the above conclusion. However, the basin of deposition was not of marginal or orthogeosynclinal

* Assistant Professor Hisashi Kusumi of the Hiroshima University kindly gave me an opportunity to examine for comparison some selected sandstone samples of his collections from the Sasayama series.

** e.g. Nobuhide Murakami, to be published. 
type, but rather a brachygeosyncline developed between the slowly rising mountains, so that the condition was not suitable for giving rise to turbidity currents. No remarkable graded bedding typical of graywacke (KUENEN et al., 1950) was formed in the Mifuné group.

The conclusion regarding tectonism in source areas, from all-round considerations of the composition of the detritus, is that the sources were subjected to an epeirogenic uplifts, although the basal conglomerate of the Mifuné group is a product of orogenic episode. The history in the source area can be traced by the composition of the sediments. As a result of a rapid rising in the source areas, large volumes of coarse clastics were deposited in the earliest phase of the deposition-age of the Basal formation. During this time mainly metamorphic and acid igneous terrains were eroded in the northern source area and older sedimentary rocks in the southern one. Therefore continued uplift in the source areas resulted in more extensive erosion of metamorphics mainly in the north, granitic rocks and sedimentaries in the south.

\section{Comparative remarks of the Mifune group}

As to the geological signifiance of the Mifuné group, further comparative study with other similar deposits is needed. In this respect, I give herein some comparative remarks of the Mifuné red beds with other well-investigated ones, although comprehensive study of other contemporaneous sediments with red beds in Middle Kyushu is not yet completed.

Red sediments remind us of the classical Torridon Sandstone, Old Red Sandstone (for petrological references, see HEARD et al., 1924; FleEt, 1926), and New Red Sandstone (see also ThомAs, 1909) of Great Britain and the Keweenawan, Catskill, Monongahera, Dunkard, Newark series, and others of the United States.

All things considered, the Triassic Newark series of Connecticut is most interesting to be referred to for comparison with the Mifuné group. According to KRYNINE (1950), the Newark consists of a sedimentary wedge constituting a series of fault troughs along the axis of the Appalachians. Poorly sorted heterogenious deposits of Newark, maximum 25,000 feet thick, consist of coarse, gray and pink, fluvial arkose, conglomerates, red feldspathic sandstones, and red siltstones and shales. They occupy the fault troughs which took place in the complex systems comprising a narrowly extended belt of unaltered Paleozoic sediments and a belt of the Piedmont Province of granites, gneisses, and schists. KRYNINE, as an interpretation of red coloration of the Newark, postulated a savanna climate with warmth and heavy rainfall over both the source areas and the basin of deposition.

Thus, it is noteworthy that the Mifuné red beds of a moderate thickness is also rather a graben-deposits on the basement of unaltered Paleozoic sediments and crystalline metamorphics. However, the Newark is characterized by high content of 
feldspar in that arkosic lithotope is resulted. In contrast with the Newark series the Mifuné group is poor in feldspar content, presenting a graywacke facies. According to PetTiJohn (op.cit., p. 643), that Newark series and certain other examples do not seem to be a molasse but are instead local terrestrial valley or graben facies and not necessarily orogenic in character. As KAY (1949, p. 136) has suggested, provenance rather than tectonism is believed to be the cause of the major sedimentary facies. For this and other problems Mifuné group seems to supply us an interesting example. Before going into too much generalization, I should study the sediments of the Goshonoura group which is nearly contemporaneous with and displayed adjacent to the Mifuné group.

\section{References Cited}

Beveridae, A. J. and Folinsbee, R. E. (1956): Dating Cordilleran Orogenies. Trans. Roy. Soc. Canada, 50, Ser. 3, Sec. 4, 19-43, figs. 1-4, pls. 1-10.

Bokman, John (1953): Lithology and petrology of the Stanley and Jackfork formations. $J$. Geol., 61, (4), 152-169, figs. 1-5, tables 1-3, pl. 1.

Clarke, F. W. (1924): The data of geochemistry. U. S. Geol. Survey, Bull., 770, 1-841.

Crowley, A. J. (1939): Possible criterion for distinguishing marine and non-marine sediments. Bull. Am. Assoc. Petroleum Geol., 23, (11), 1716-1720, figs. 1-4.

Dapples, E. C., Krumbein, W. C., and Sloss, L. L. (1953): Petrographic and lithologic attributes of sandstones. J. Geol., 61, (4), 291-317, figs. 1-11, table 1.

Dryden, L. (1935): A statistical method for comparison of heavy mineral suites. Am. J. Sci., 29, (173), 393-408, fig. 1, tables I-5.

FLEET, W. F. (1926): Petrological notes on the Old Red Sandstone of the West Midlands. Geol. Mag., 43, (11), 505-516, table 1, pl. 29.

Folk, Robert L. and Weaver, Charles Edward (1952): A study of the texture and composition of chert. Am. J. Sci., 250, (7), 498-510, fig. 1, pls. 1-4.

FuJI, Koji (1953): Some problems on the studies of sandstone (in Japanese with English résumé). Chikyu-Kagaku [Earth Science], (20), 9-18.

(1956): Sandstones of the Mesozoic formations in the Yatsushiro district, Kumamoto Prefecture, Kyushu, Japan (in Japanese with English résumé). J. Geol. Soc. Japan, 62, (727), 193-211, figs. 1-10, tables 1-10, pl. 3.

(1958): Petrography of the Cretaceous sandstone of Hokkaido, Japan. Mem. Fac. Sci., Kyushu Univ., [D], Geol., 6, (3), 129-152, figs. 1-7, tables 1-7, pl. 23.

Fuлгмото, Masataro and НАsнiмото, Mitsuo (1960): Plutonic and metamorphic rocks of the Konohayama-Kunimiyama region, Kyushu (in Japanese with English résumé). J. Geol. Soc. Japan, 66, (772), 27-34, figs. 1-3, tables 1-2, pl. 3.

Goddard, E. N. [Chairman] (1951): Rock-color chart [2nd Ed.]. Rock-Color Chart Committee, Geol. Soc. Am., N. Y.

HASE, Akira (1958): The stratigraphic and geologic structure of the late Mesozoic formations in western Chugoku and northern Kyushu (in Japanese with English résumé). Rept. Geol., Hiroshima Univ., (6), 1-50, figs. 1-5, tables1-7, pls. 1-14.

Heard, Albert and Davies, Richard (1924): The Old Red Sandstone of the Cardiff District. Q.J.G.S., 80, (4), 489-515, figs. 1-2, table 1; with discussion, Ibid., 516-519.

Helmbold, Reinhard (1952): Beitrag zur Petrographie der Tanner Grauwacken. Heidelberger Beitr. Min. Petr., 3, 253-288.

Iлмма, Azuma (1959a): On the difference between the Cretaceous and the Paleogene Tertiary systems, considered from heavy mineral associations (in Japanese). Yukochu [Foraminifera], (10), 73-80. 
$(1959 b)$ : On relationship between the provenances and the depositional basins, considered from the heavy mineral associations of the Upper Cretaceous and Tertiary formations in central and southeastern Hokkaido, Japan. J. Fac. Sci., Univ. Tokyo, Sec. II, 11, (4), 339-385, figs. 1-25, tables 1-35, pls. 21-23.

KaRAKIDA, Yoshifumi (1952): Geological relations among granitic rocks in North Kyushu, Japan (abstract) (in Japanese). J. Geol. Soc. Japan, 58, (682), 277.

(1954): The presence of "Zircon Zone" along a Cretaceous granodiorite-granite contact in North Kyushu (in Japanese with English résumé). Ibid., 60, (711), 517-532, figs. 1-10, tables 1-3.

Kay, Marshall (1949): Cited in Petrijohn's (1957).

Kobayaser, Teiichi (1941): The Sakawa orogenic cycle and its bearing on the origin of the Japanese islands, J. Fac. Sci., Imp. Univ. Tokyo, Sec. II, 5, (7), 219-578, figs. 1-55, pls. 1-4.

(1954): The origin of the Japanese islands and the Sakawa orogenic cycle-An introduction to the regional geology of Japan (in Japanese). i-xv, 1-352, figs. 1-68, tables 117, pls. 1-4, Asakura Book Co., Tokyo.

Kobayashi, Teiichi and Matsumoto, Tatsuro (1936): Geologic structure of southwestern Japan and its Mesozoic paleogeography (in Japanese with English résumé). J. Geol. Soc. Japan, 43, (514), 542-550.

Krumbein, W. C. (1935): Thin section mechanical analysis of indurated sediments. J. Geol., 43, (5), 482-496, figs. 1-7, tables 1-6.

(1936): Application of logarithmic moments to size frequency distributions of sediments. J. Sed. Petrol., 6, (1), 35-47, figs. 1-5, tables 1-2.

(1941): Measurement and geological significance of shape and roundness of sedimentary particles. J. Sed. Petrol., 11, (2), 64-72, figs. 1-5, tables 1-4, pl. 1.

Krumbein, W. C. and Petrijoen, F. J. (1938): Manual of sedimentary petrography. i-xiv, 1-549, figs. 1-265, tables 1-53, Appleton-Century-Crofts, Inc., New York.

KRUMBEIN, W. C. and Garrels, R. M. (1952): Origin and classification of chemical sediments in terms of $\mathrm{pH}$ and oxidation-reduction potentials. J. Geol., 60, (1), 1-33, figs. 1-8, tables 1-6.

Krynine, P. D. (1940): Petrology and genesis of the Third Bradford Sand. Penn. State Coll. Mineral Ind. Expt. Sta., Bull., 29, 1-134.

(1946): The tourmaline group in sediments. J. Geol., 54, (2), 65-87, figs. 1-17, tables

(1950): Petrology, stratigraphy, and origin of the Triassic sedimentary rocks of Connecticut. Connecticut State Geol. and Nat. Hist. Survey, Bull., 73, 1-239.

Kuenen, Ph. H. and Migliorini, C. I. (1950): Turbidity currents as a cause of graded bedding. J. Geol., 58, (2), 91-127, figs. 1-7, tables 1-3, pls. 1-5.

Kusumi, Hisashi (1958): On the Kenseki group in the eastern part of the Chugoku district (western Honshu) (in Japanese). The Synthetic study of the Late Mesozoic of Japan [Mimeograph], (7), 143-144.

Matsumoto, Tatsuro (1936): Geology of the Onogawa basin (in Japanese with English résumé). J. Geol. Soc. Japan, 43, (517), 758-780, figs. 1-4, tables 1-7, pl. 43; Ibid. (518), 815-852, figs. 1-5, pl. 47.

(1938): Geology of the Goshonoura island, Amakusa, with special reference to the Cretaceous stratigraphy (in Japanese with English appendix). Ibid., 45, (532), 1-46, figs. 1-12, tables 1-7, pls. 1-4.

(1939a): Geology of the Mifuné district, Kumamoto Prefecture, Kyushu (in Japanese with English résumé). Ibid. 46, (544), 1-12, figs. 1-2, table 1, pl. 1.

$(1939 b)$ : Some geological problems concerning the central zone of Kyushu (the “Nagasaki Dreiecke”) (in Japanese with English résumé). Ibid., 46, (550), 366-382.

(1953): The Mesozoic era (in Japanese). Chikyu-Kagaku [Earth-Science], (15), 12-15, tables 1-5.

[Editor] (1954): The Cretaceous system in the Japanese islands. i-xiv, 1-324, figs.

1-77, tables 1-2, pls. 1-36, Iapan Soc. Prom. Sci., Tokyo. 
Matsumoto, Tatsuro and Fujimoto, Haruyoshi (1939): On a formation belonging to the Titibu system in Kamimasuki-gun, Kamamoto-ken, Kyushu (in Japanese with English résumé). $J$. Geol. Soc. Japan, 46, (547), 189-192.

Matsumoto, Yukuo and Tomita, Tôru (1953): Difference in crystal habits between plutonic and volcanic zircons (abstract) (in Japanese). J. Geol. Soc. Japan, 59, (694), 361-362.

Matsushita, Susumu (1953): Kinki-chiho [Kinki district]-Regional geology of Japan (in Japanese). i-vii, 1-299, figs. 1-45, table 1-8, Asakura Book Co., Tokyo.

Milner, Henry B. (1952): Sedimentary petrology [3rd Ed.]. i-xix, 1-666, figs. 1-100, pls. 1-52, Thomas Murby \& Co., London.

Miyashiro, Akiho (1958): On the study of glaucophanatic metamorphism (in Japanese with English résumé). J. Geol. Soc. Japan, 64, (750), 146-151.

(1959): Abukuma, Ryoke, and Sanbagawa metamorphic belts (in Japanese with English résumé). Ibid., 65, (769), 624-637.

Miyashiro, Akiho and Banno, Shohei (1958): Nature of glaucophanatic metamorphism. Am.J. Sci., 256, (2), 97-110.

Mizutani, Shinjiro (1957): Permian sandstones in the Mugi area, Gifu Prefecture, Japan. $J$. Earth Sci., Nagoya Univ., 5, (2), 135-151, figs. 1-8, tables 1-2, pl. 1.

OкарA, Hakuyu (1957): On the heavy mineral composition of the Cretaceous Mifuné group, Kyushu (in Japanese). The Synthetic Study of the Late Mesozoic of Japan [Mimeograph], (7), 191-165, table 1.

(1958): Matsumotoa: a new priondont pelecypod genus from the Cretaceous Mifuné group, Kyushu, Japan. Mem. Fac. Sci., Kyushu Univ., [D], Geol., 8, (2), 35-48, figs. 1-5, pls. 10-11.

OKaDA, Hakuyu and OGURI Hisakazu (1960): Sandstones of the Cretaceous Goshonoura group, Kyushu, Japan (abstract) (in Japanese). J. Geol. Soc. Japan, 66, (778), 466-467.

Onoyama, Takefumi (1931): Geology of the Sasayama basin, Province of Tamba (in Japanese). Chikyu [Earth], 16, (3), 159-167, pl. 4.

Pettijohn, F. J. (1957): Sedimentary rocks [2nd Ed.]. i-xvi, 1-718, figs. 1-173, tables 1-118, pls. 1-40, Harper \& Brothers, New York.

Pirsson, L. V. (1915): The microscopical characters of volcanic tuffs. Am. J. Sci., 40, (236), 191-211, figs. 1-6.

Poldervalkt, A. (1955): Zircon in rocks. 1. Sedimentary rocks. Ibid., 253, (8), 433-461, figs. $1-12$, tables $1-7$.

(1956) : Ditto 2. Igneous rocks. Ibid., 254, (8), 521-554, figs. 1-10, tables 1-5.

Potter, Paul Edwin and Siever, Raymond (1956): Sources of basal Pennsylvanian sediments in the Eastern Interior Basin. 2. Sedimentary petrology. J. Geol., 64, (4), 317-335, figs. 1-5, tables 1-5.

Seri, Yotaro (1958): Glaucophanatic regional metamorphism in the Kanto Mountains, central Japan. Japan J. Geol. Geogr., 29, 233-258.

ShIKI, Tsunemasa (1958): Studies on sandstones in the Maizuru Zone, Southwest Japan I. Mem. Coll. Sci., Univ. Kyoto, Ser. B, 25, (4), 239-246, figs. 1-5.

Shirozo, Haruo and TaNAKa, Bungo (1958): On green sandstones of the Kishima group in the Karatsu coal field, with special reference to green minerals (in Japanese with English résumé). J. Mining Inst. Kyushu, 27, (3), 130-134, figs. 1-2, tables 1-4.

Suzuki, Jun (1932): Study of Mesozoic tuffaceous rocks in Japan (in Japanese). J. Geol. Soc. Japan, 39, (471), 727-747, tables 1-4, pl. 6.

Thomas, H. H. (1909): A contribution to the petrography of the New Red Sandstone in the West of England. Q.J.G.S., 65, (259), 229-244, tables 1-2, pl. 12.

Tомiтs, Tôru (1954): Geologic significance of the color of granite zircon, and the discovery of the Pre-Cambrian in Japan. Mem. Fac. Sci., Kyushu Univ., Ser. D, Geol., 4, (2), 135-161, tables 1-3.

Tomita Tóru and Karakida, Yoshifumi (1957): Granite pebbles of the Paleozoic and Mesozoic formations in Japan (in Japanese). The Synthetic Study of the Late Mesozoic of Japan [Mimeograph], (5), 9-15, table 1. 
UyedA, Yoshiro (1957): Geology of the Shimonoseki district, with special reference to the Kwanmon group (in Japanese with English résumé). I. Geol. Soc. Japan, 63, (736), 26-34, figs. 1-2, table 1 , pl. 1 .

Van Houten, F. B. (1948): The origin of red-banded early Cenozoic deposits in Rocky Mountain region. Bull., Am. Assoc. Petroleum Geol., 32, (11), 2083-2126, figs. 1-3, tables 1-3.

-__ranslator] (1958): Contribution to the petrography of the Tanner graywacke. Bull. Geol. Soc. Am., 69, (3), 301-314, figs. 1-5, tables 1-6.

Weaver, Charles E. (1955): Mineralogy and petrology of the rocks near the Quadrant-Phosphoria boundary in southwest Montana. J. Sed. Petrol., 25, (3), 163-192, figs. 1-11, tables 1-4.

Yanagida, Juichi (1958): The Upper Permian Mizukoshi formation (in Japanese with English résumé). J. Geol. Soc. Japan, 64, (752), 222-231, figs. 1-2, tables 1-2.

Үамамото, Hirosato (1955): Behaviour of zircons in the contact zone between the Chikugo metamorphic rocks and the Tamana granodiorite (in Japanese). Mem. Fukuoka Lib. Arts Coll., (5), 59-67.

Yамамото, Takashi (1959): Zircons in volcanic rocks (in Japanese). J. Japan. Assoc. Min., Petr., Econ. Geol., 43, (6), 282-296, figs. 1-8, tables 1-4.

\section{Addenda :}

Krynine, P. D. (1949): The origin of red beds. New York Acad. Sci. Trans., Ser. 2, 2, 60-68. Swineford, Ada (1955): Petrography of Upper Permian rocks in south-central Kansas. State Geol. Surv. Kansas Bull. 111, 1-179, figs. 1-13, tables 1-8, pls. 1-24.

Corrigenda for Text-fig. 1:

Read

1: Quaternary

8: "Kiyama**** crystalline schists"

11: Boundary of the formations

$\mathrm{Kw}$ :

Nk :

\section{For}

1: Quarternary

8: “Kiyama"**** crystalline shist

11: Bounday of the formations

KW :

Fk: 
Hakuyu OKADA

Sandstones of the Cretaceous Mifuné Group, Kyushu, Japan

Plates 1-5 
Plate 1 


\section{Explanation of Plate 1}

Fig. 1. Basal conglomerate of the Mifune group at the type locality of the Basal formation, exposed in the Kanayama, about $3.4 \mathrm{~km}$ upstream from its junction with the Kiyama and about $200 \mathrm{~m}$ west of Sarugayeri, Kawaharu-mura, Kamimasukigun, Kumamoto Prefecture; loc. MF. 0018.

Fig. 2. Massive sandstone on the northern wing of the Lower formation, exposed on the Akai; loc. MF. 1010.

Figs. 3, 4. Typical greenish sandstone intercalated in red siltstone of the Upper formation.

3. Exposure in quarry face on the prefectural road, about $250 \mathrm{~m}$ south of Nakano, Mifuné-machi, Kamimasuki-gun; loc. MF. 2048.

4. Detail of the ditto. Note well-developed lamination.

Fig. 5. Intercalation of greenish sandstone bed between red silstone beds of the Upper formation; about $500 \mathrm{~m}$ southeast of Nakano.

Fig. 6. Reddish blocky shale with thin zeolite vein (white) along the bedding plane, exposed behind the shrine on the Yagata, Kitakinokura, Mifuné-machi; loc. MF. 2111.

Photos by H. Orada. 

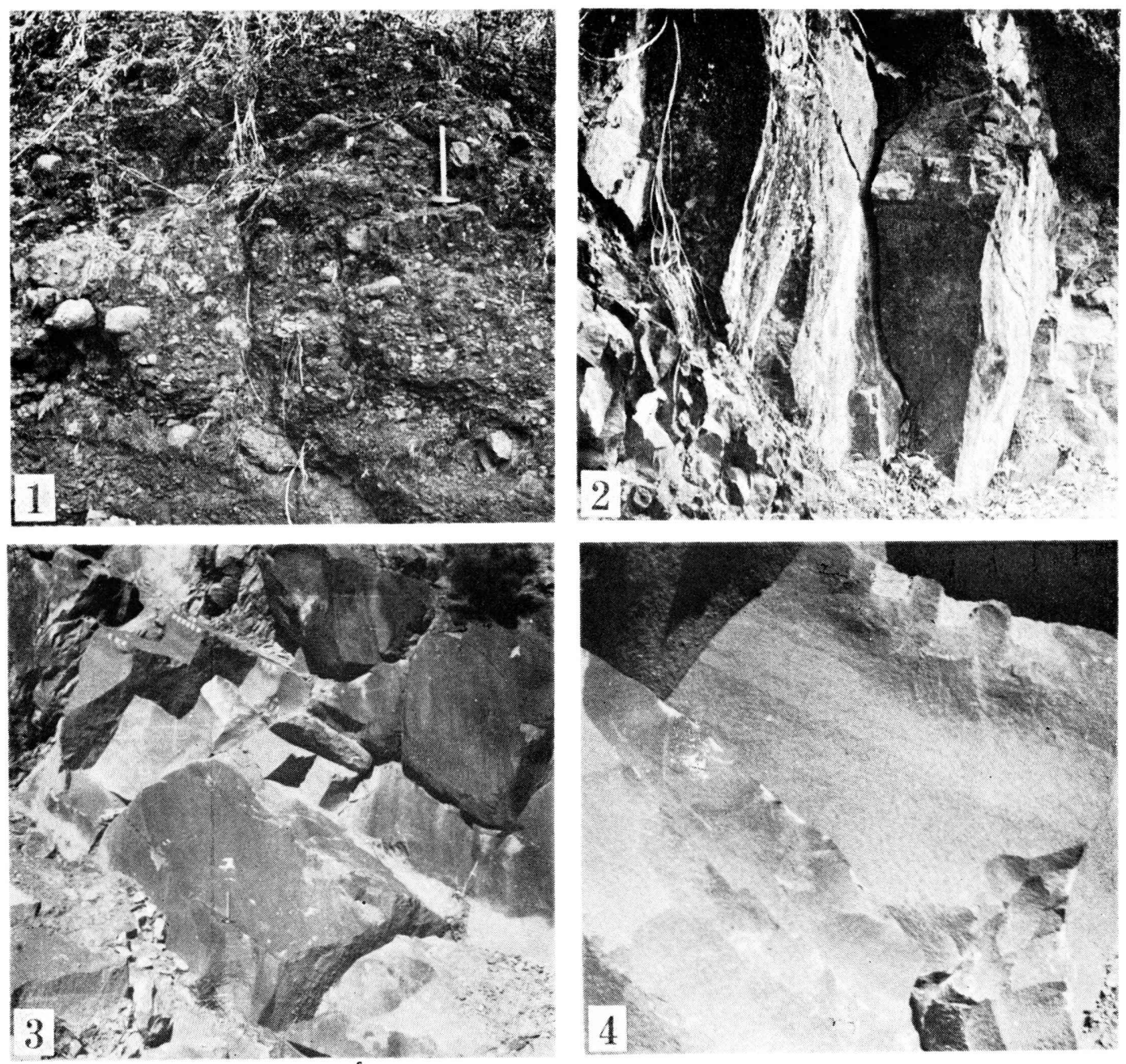

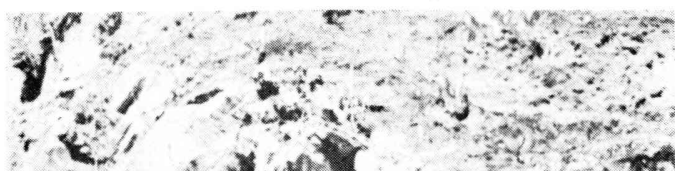
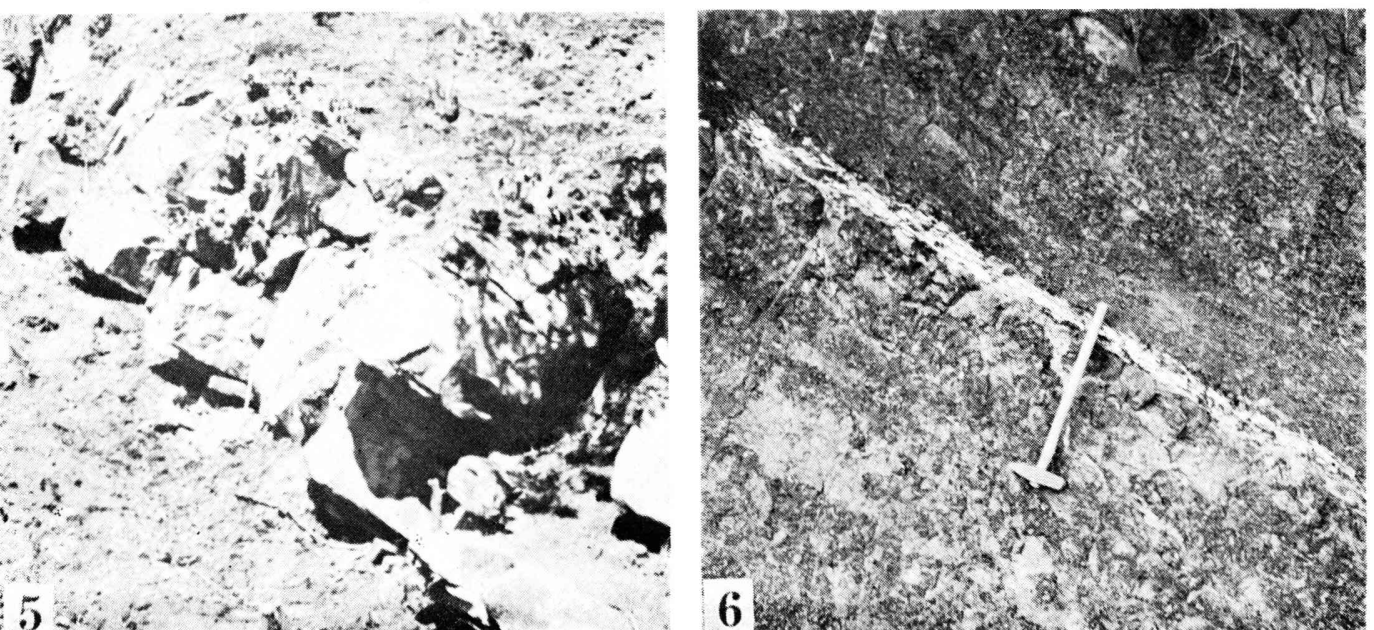
and 10

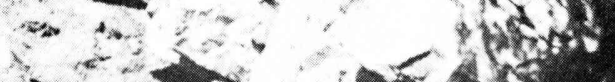

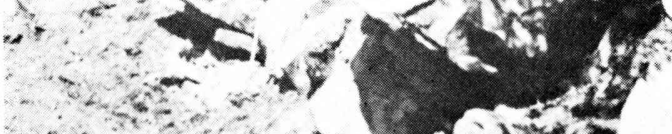

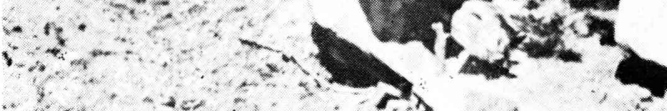

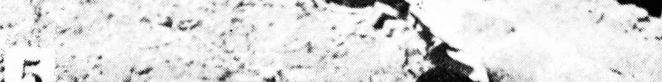

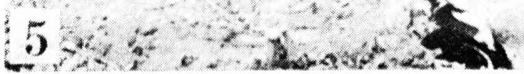

6 - 
Plate 2 


\section{Explanation of Plate 2}

Figs. 1-8. Examples of graywacke sandstones of the Mifune group in thin section (photo micrographs). All figures are of crossed nicols; $\times 50$

1. MF. 1001a, from the northern wing of the Lower formation.

2. MF. $1009 \mathrm{a}$, ditto.

3. MF. 1015a, ditto.

4. MF. 1015 b, ditto.

In the above, note the preponderance of the metamorphic quartz grains.

5, 6. MF. 1057, from the southern wing of the Lower formation.

7. MF. 1050, ditto.

8. MF. 2090, from the Upper formation.

Photos by H. ОкарA. 
Mem. Fac. Sci., Kyushu Univ., Ser. D, Vol. X
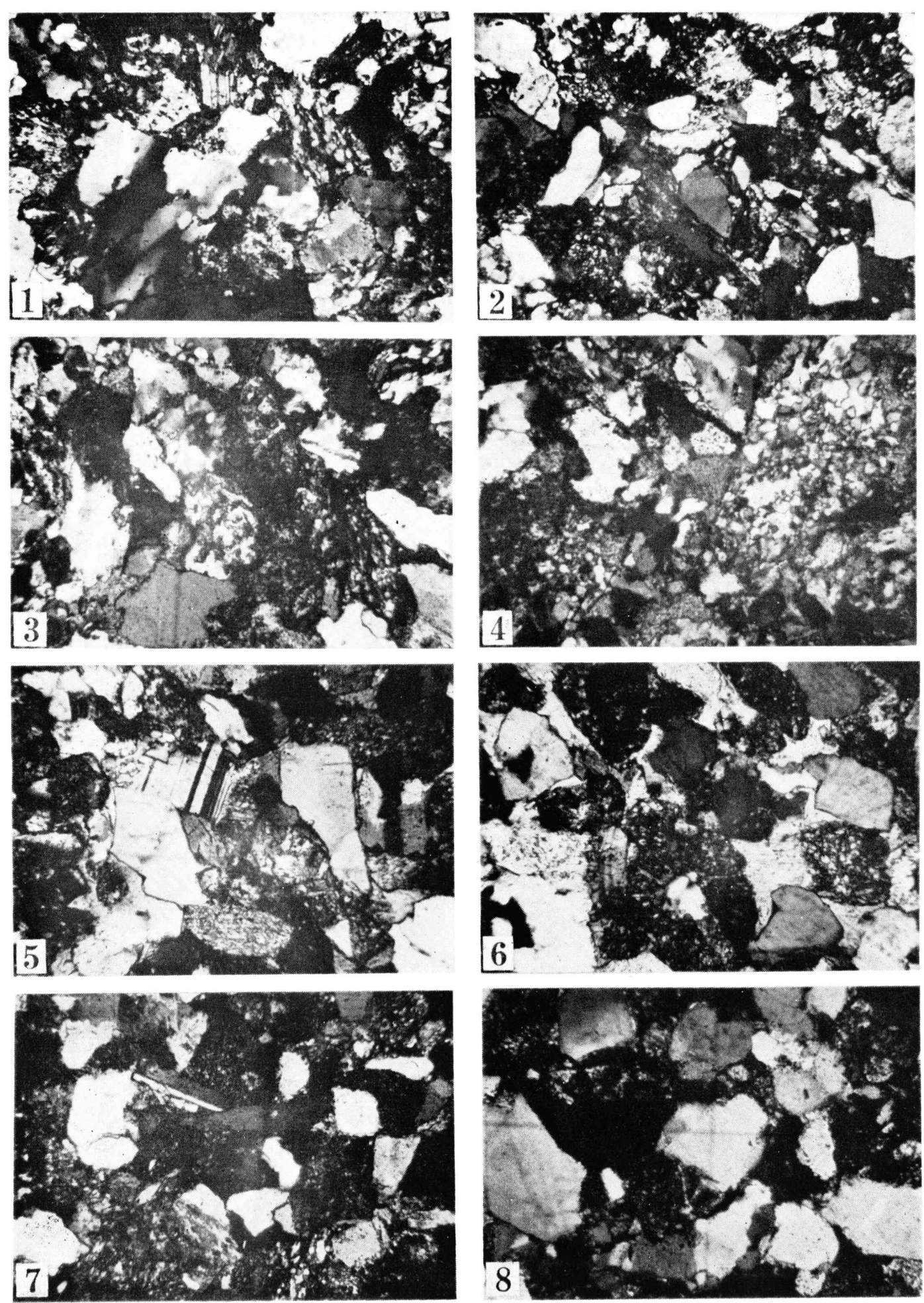
Plate 3 


\section{Explanation of Plate 3}

Figs. 1-6. Photomicrographs of red siltstone, tuffite, and tuffaceous sandstone. All figures are of open nicols; $\times 65$.

1. MF. 2015, red sandy siltstone of the Upper formation.

2. MF. 1070', dacitic tuffite of the Lower formation.

3. MF. 1007, dacitic tuffite of the Lower formation.

4. MF. 2014, dacitic tuffite of the Upper formation.

5. MF. 1021, tuffaceous sandstone of the Lower formation.

6. MF. 2058c, tuffaceous sandstone of the Upper formation.

Photos by H. Orada. 

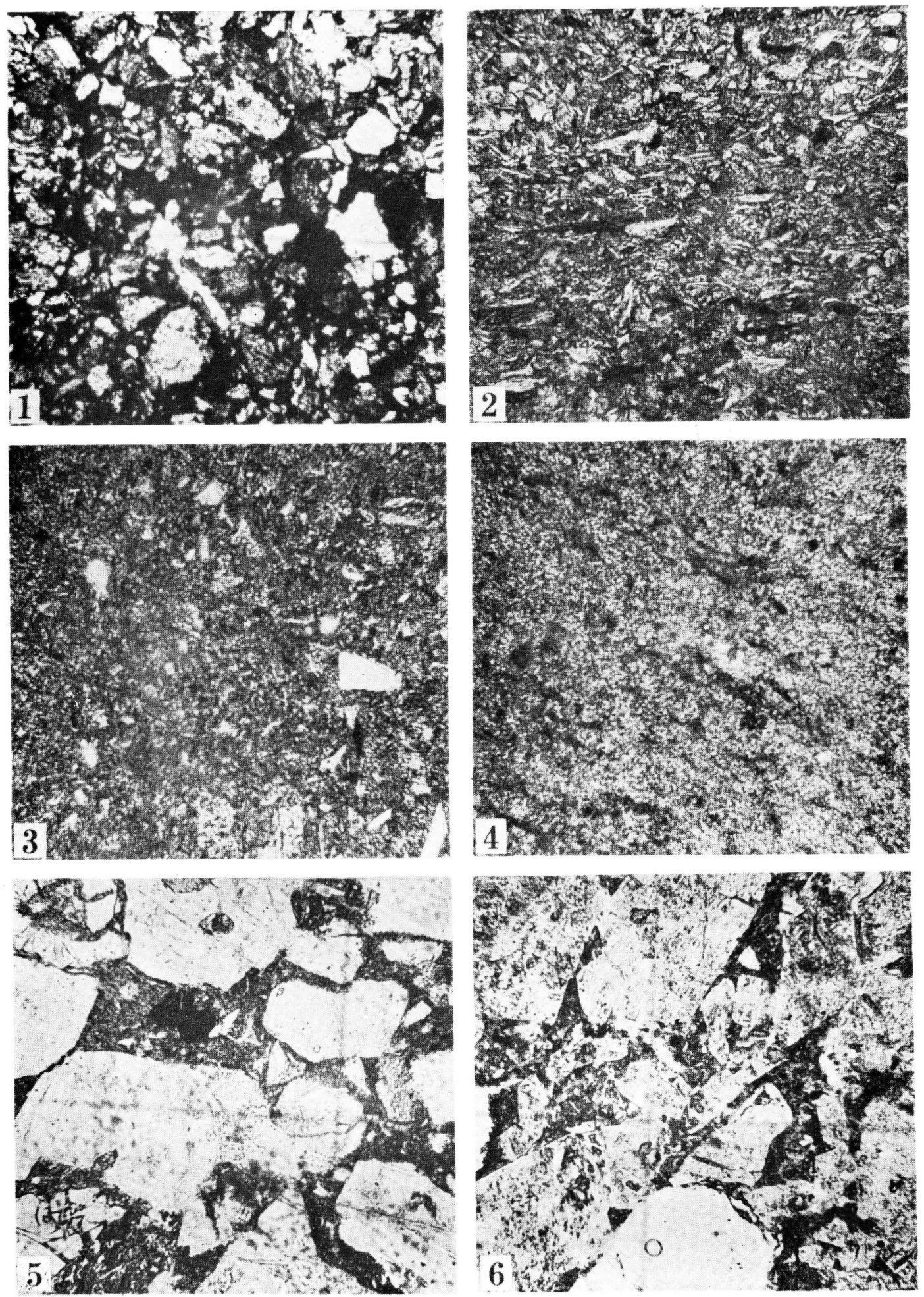


\section{Plate 4}




\section{Explanation of Plate 4}

Fig. 1. Euhedral zircon with a large inclusion parallel to the $c$-axis; MF. 1032.

Fig. 2. Euhedral zircon with irregularly oriented inclusions; MF. 0010.

Fig. 3. Purple zircon: high degree of rounding, fissures infilled with opaque materials, cavity, and staining; MF. 2092.

Fig. 4. Rounded purple zircon; MF. 0010.

Fig. 5. Rounded purple zircon; MF. 0003 .

Fig. 6. Rounded purple zircon with spherical inclusion; MF. 0005.

Fig. 7. Rounded purple zircon; MF. 0005.

Fig. 8. Epidote grain: slight rounding; MF. 1001.

Fig. 9. Epidote grain: cleavage; MF. 2100.

Fig. 10. Garnet fragment; MF. 0010.

Fig. 11. Garnet; MF. 0010.

Fig. 12. Garnet; MF. 1018.

Fig. 13. Garnet; MF. 2132.

Fig. 14. Garnet euhedron: surface fissures; MF. 0010.

Fig. 15. Garnet euhedron: crystal form; MF. 1003; $\times 200$.

Fig. 16. Garnet euhedron; MF. 2100.

Fig. 17. Garnet euhedron: etching; MF. 0011.

Fig. 18. Garnet euhedron ; 2097.

Fig. 19. Rounded garnet; MF. 1028.

Fig. 20. Garnet euhedron: slight degree of rounding and etched surface; MF. 0003.

All figures $\times 250$, if otherwise mentioned.

Photos by H. Orada. 

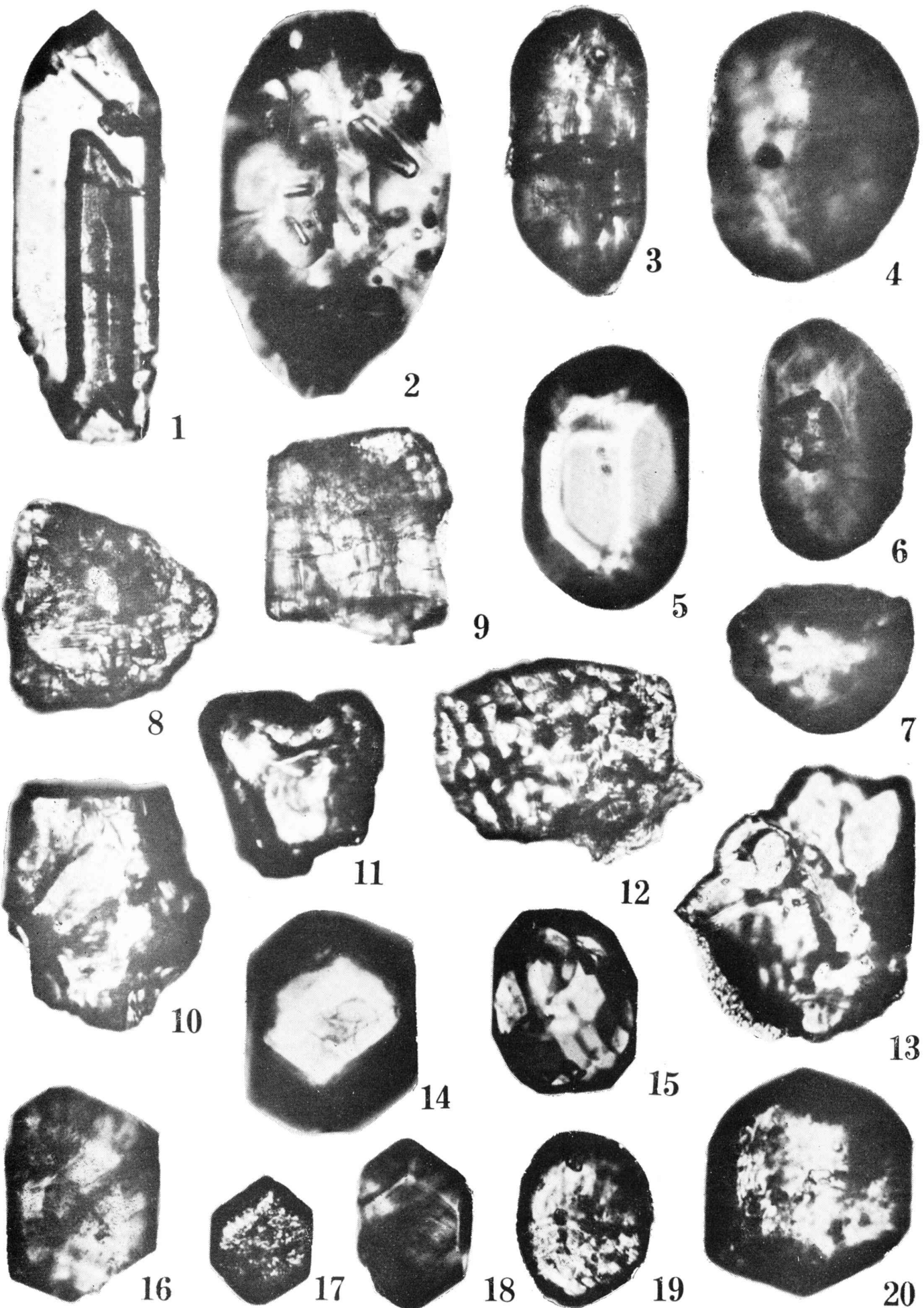

12
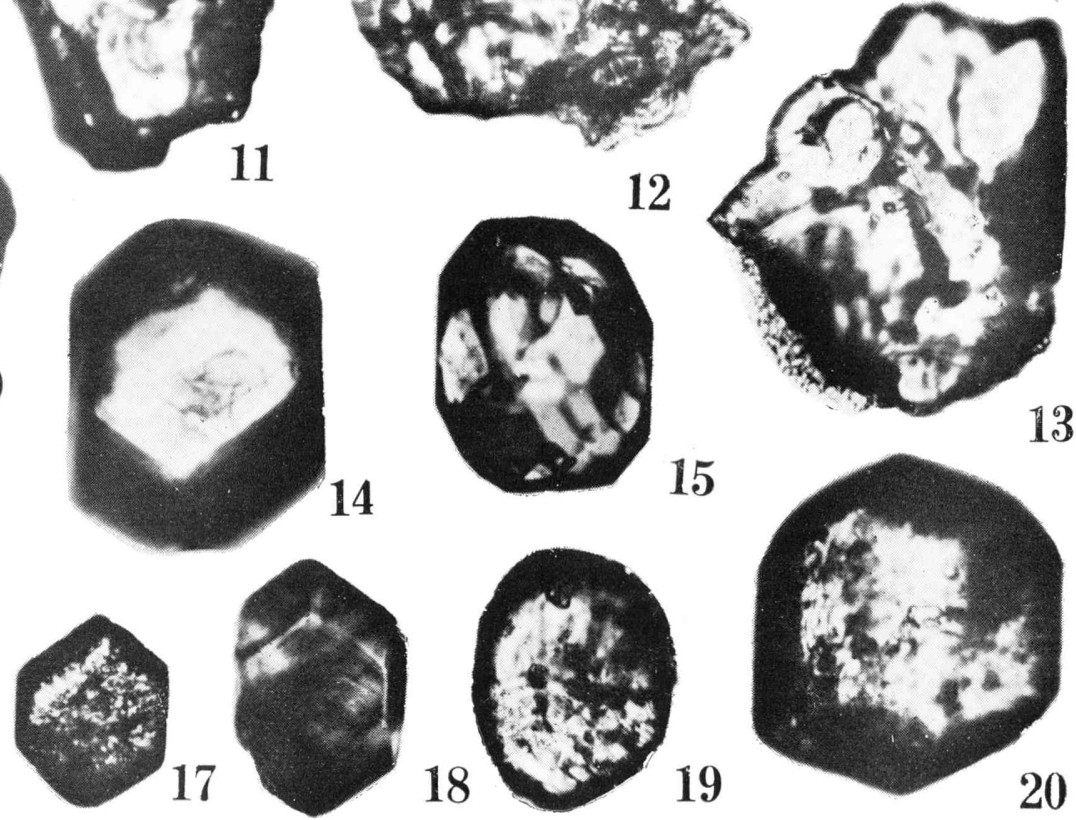
Plate 5 


\section{Explanation of Plate 5}

Fig. 1. Brown tourmaline: cavities; MF. $2100 ; \times 375$.

Fig. 2. Brown tourmaline: cleavage; MF. 2100.

Fig. 3. Brown tourmaline; MF. 2097.

Fig. 4. Tourmaline fragment: green; MF. 1014.

Fig. 5. Green tourmaline; 2097.

Fig. 6. Tourmaline fragment: inclusion and cleavage; MF. 2097

Fig. 7. Rounded purple zircon; MF. 1020.

Fig. 8. Glaucophane; MF. 0011.

Fig. 9. Green hornblende; MF. 1018.

Fig. 10. Rutile; MF. 0011.

Fig. 11. Rutile euhedron: radial fissures; MF. 0006.

Fig. 12. Anatase euhedron; MF. 0011.

Fig. 13. Anatase euhedron; MF. 0011.

Fig. 14. Anatase euhedron; MF. 0010.

Fig. 15. Titanite euhedron; MF. 1010.

Fig. 16. Apatite: rod-shaped inclusions; MF. 1025; $\times 350$.

Fig. 17. Apatite euhedron; MF. $1025 ; \times 350$.

Fig. 18. Apatite; MF. 1025; $\times 350$.

Fig. 19. Apatite; MF. 1025 ; $\times 350$.

All figures $\times 250$, if otherwise mentioned.

Photos by H. OKaDA. 

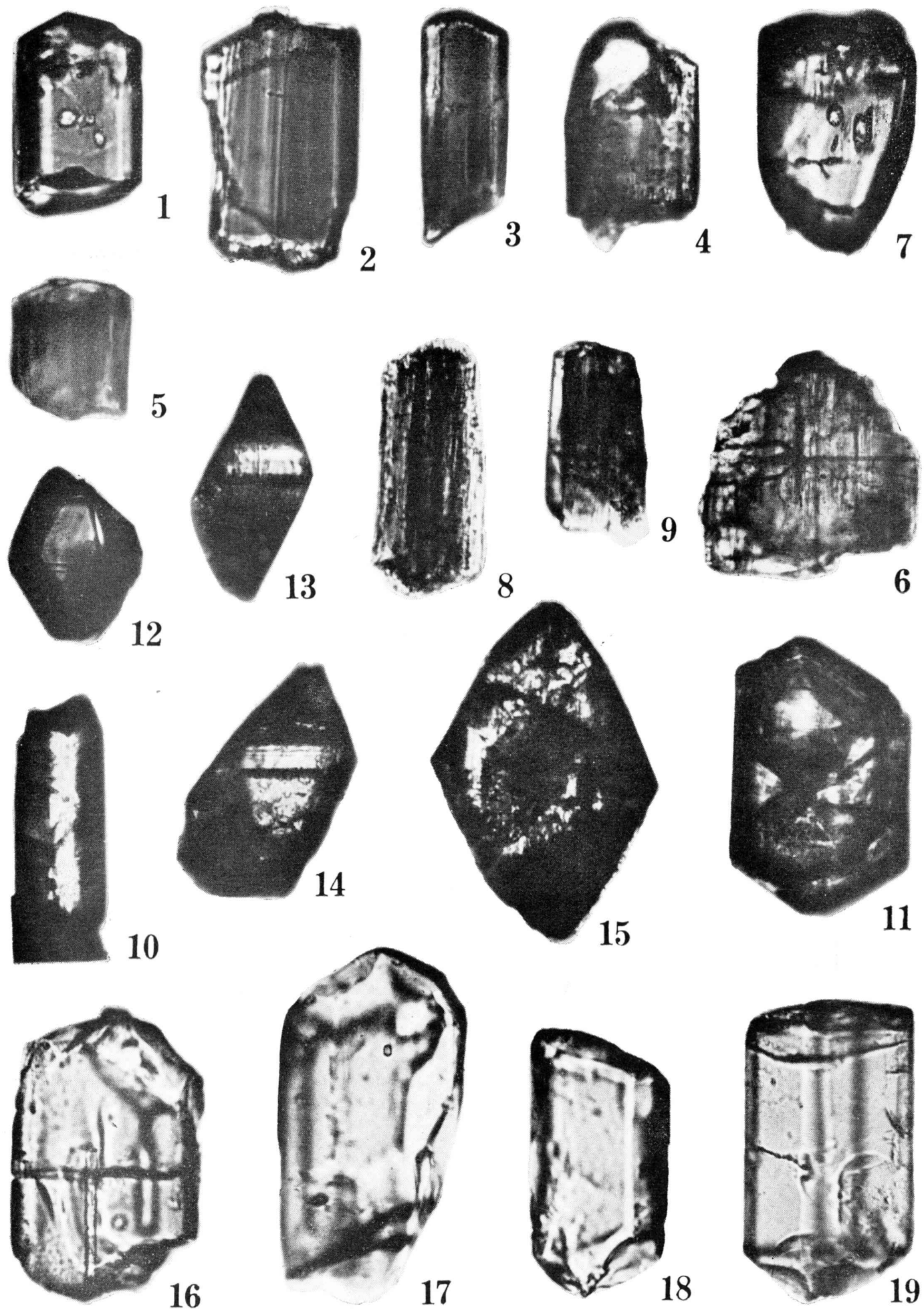